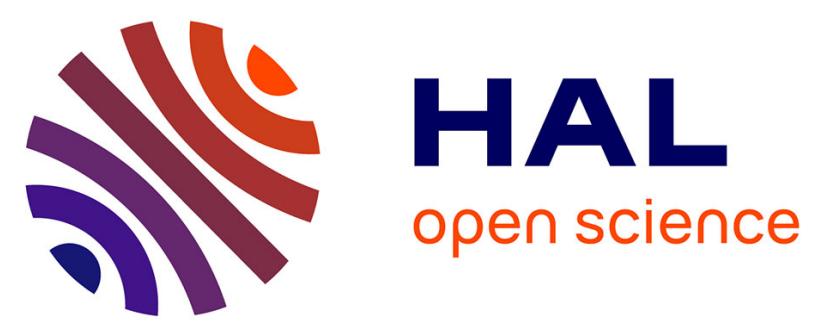

\title{
Holocene relative sea-level changes in western Brittany (France) between 7600 and 4000 cal. BP: Reconstitution from basal-peat deposits.
}

\author{
Jérôme Goslin, Brigitte van Vliet-Lanoë, Pierre Stéphan, Christophe \\ Delacourt, Assia Fernane, Emmanuel Gandouin, Alain Hénaff, Aurélie \\ Pénaud, Serge S. Suanez
}

\section{To cite this version:}

Jérôme Goslin, Brigitte van Vliet-Lanoë, Pierre Stéphan, Christophe Delacourt, Assia Fernane, et al. Holocene relative sea-level changes in western Brittany (France) between 7600 and 4000 cal. BP: Reconstitution from basal-peat deposits.. Géomorphologie: relief, processus, environnement, 2013, Systèmes géomorphologiques: renouveler les thématiques, les outils et les méthodes, 19 (4), pp.425444. 10.4000/geomorphologie.10386 . hal-00926221

\section{HAL Id: hal-00926221 \\ https://hal.science/hal-00926221}

Submitted on 17 Jul 2017

HAL is a multi-disciplinary open access archive for the deposit and dissemination of scientific research documents, whether they are published or not. The documents may come from teaching and research institutions in France or abroad, or from public or private research centers.
L'archive ouverte pluridisciplinaire $\mathbf{H A L}$, est destinée au dépôt et à la diffusion de documents scientifiques de niveau recherche, publiés ou non, émanant des établissements d'enseignement et de recherche français ou étrangers, des laboratoires publics ou privés. 


\title{
Holocene relative sea-level changes in western Brittany (France) between 7600 and 4000 cal. BP: Reconstitution from basal-peat deposits
}

\section{Variations du niveau marin relatif holocène dans l'ouest de la Bretagne (France) : reconstitution à partir des tourbes de base entre 7600 et $4000 \mathrm{cal}$. BP}

\author{
Jérôme Goslin*, Brigitte Van Vliet-Lanoë**, Pierre Stephan*, Christophe Delacourt**, Assia
}

Fernane**, Emmanuel Gandouin***, Alain Hénaff*, Aurélie Penaud**, Serge Suanez* $^{*}$

\begin{abstract}
With respect to others European oceanic facades, the Holocene relative sea-level (RSL) changes along the French Atlantic coasts have received relatively little attention. Even if it received some attention for geophysical modelling (Van de Plassche, 1991; Lambeck, 1997; Leorri et al., 2012), only two field-based studies really dealt with this subject in Western Brittany, agreeing on an oscillatory RSL pattern with a conspicuous pluri-metre negative variation occurring around 3000 BP (Morzadec-Kerfourn, 1974; Stephan, 2011). This paper is the first step on the way to update Western Brittany Holocene RSL data. It presents a new long-term Holocene RSL reconstruction based on basal peat deposits, compaction-free deposits that have been accumulated on top of the Pleistocene formations during the early-Holocene stages of the post-glacial transgression. Data used for the sea-level reconstruction are both new data and previously published datasets we have reassessed. New cores, extracted along the Finistère peninsula in the framework of a coastal risk assessment research program, allowed us to collect new stratigraphic data. Dates initially published on basal peat deposits in previous studies (Morzadec-Kerfourn, 1974) were re-assessed through the same process to allow their incorporation in a combined dataset. In the absence of microfossils in most of our deposits, an alternate approach was used to determine the salinity regime of the basal peat deposit environments through the use of stable carbon isotope ratios and the observation of macro-botanical remains: brackish peat deposits were used as sea-level index points, while freshwater ones provided only high-limiting constraints. Eight new radiocarbon datings were obtained. A total of six new sea-level index-points and six new limiting points allowed us to derivate the long-term (millennial) changes in RSL in Western Brittany. A comparison of these data with some foraminifera-based regional RSL data shows that both data sets closely match. Altogether, the combined data show the RSL bending $c a .7000$ and 3000 cal. BP, indicating progressively decreasing rising rates. Further work is needed to fill the centennial to pluri-centennial gaps that remain to ascertain potential periods of stability or strong decrease in the rising rates of the RSL ca. $6200 \pm 500$ and $3000 \pm 500 \mathrm{BP}$.
\end{abstract}

Key words: Holocene, RSL, basal peats, Brittany, stable C isotopes.

\section{Résumé}

En comparaison des autres façades océaniques européennes ayant déjà fait l'objet de nombreux travaux sur le niveau marin relatif holocène, les côtes atlantiques françaises demeurent quelques peu ignorées. Malgré quelques travaux de modélisation géophysique ayant intégré (entre autres) l'ouest de la Bretagne (Van de Plassche, 1991 ; Lambeck, 1997 ; Leorri et al., 2012), seules deux études, se basant sur des données de terrain, se sont véritablement intéressées au sujet (Morzadec-Kerfourn, 1974 ; Stephan, 2011). Celles-ci s'accordent sur un niveau marin relatif connaissant des oscillations au cours de l'Holocène, la plus importante devant se situer autour de 3000 BP. Cet article présente la première étape d'un travail de remise à jour des données disponibles sur le niveau marin relatif holocène dans l'ouest de la Bretagne. Les tourbes de base sont des dépôts considérés comme incompressibles (car formés soit au-dessus des formations limono-graveleuses pléistocènes ou directement sur le substrat géologique) qui représentent les premières phases de la transgression postglaciaire. Leur utilisation nous a permis de reconstituer l'évolution à long-terme du niveau marin relatif dans la région. Les données

\footnotetext{
* UMR CNRS 6554 LETG - Geomer - IUEM/Université Bretagne Occidentale - 1 place Nicolas Copernic - 29280 Plouzané - France (jerome.goslin@univ-brest.fr).

** UMR CNRS 6538 Domaines océaniques - IUEM/Université Bretagne Occidentale - 1 place Nicolas Copernic - 29280 Plouzané - France.

*** UMR CNRS 6116 IMEP - Université Paul Cézanne - Europole Méditerranéen de l’Arbois - 13545 Aix-en-Provence cedex 4 - France.
} 
mobilisées pour ce travail proviennent à la fois de nouvelles datations et de la recalibration de données précédemment publiées. Les nouvelles dates ont été obtenues à partir de carottages réalisés sur plusieurs sites autour de la pointe finistérienne, dans le cadre de l'ANR COCORISCO (Historique de la tempétuosité holocène pour l'étude des risques côtiers). En l'absence d'indicateurs micro-faunistiques dans la plupart des dépôts prélevés, les conditions de salinité du milieu de sédimentation originel ont été déterminées par l'utilisation de mesures des isotopes stables du carbone $\left({ }^{13} \mathrm{C}\right)$ et par la détermination des macro-restes végétaux. Les tourbes de base, considérées comme s'étant formées en milieu saumâtre, ont été utilisées comme "points-index» du niveau marin tandis que celles relevant d'un milieu d'eau douce ont été utilisées comme points limitants. Huit nouvelles datations radiocarbone ont été obtenues. Un total de six nouveaux pointsindex et six points limitants a permis de reconstituer les évolutions à long-terme du niveau marin relatif dans l'ouest de la Bretagne. Les résultats ont été comparés avec une reconstitution des variations du niveau marin dans la région effectuée à partir de l'étude des foraminifères. L'ensemble montre une très bonne cohérence et indique que le niveau marin relatif a connu des ralentissements de son rythme de remontée autour de 7000 et $3000 \mathrm{cal}$. BP. Des travaux supplémentaires demeurent néanmoins nécessaires dans la mesure où des doutes persistent dans les périodes autour de $6200 \pm 500$ et $3000 \pm 500 \mathrm{cal}$. BP.

Mots clés : Holocène, niveau marin relatif, tourbes de base, Bretagne, isotopes stables du carbone.

\section{Version abrégée en français}

Utilisés dans des domaines variés, les études portant sur la reconstitution du niveau marin relatif (NMR) holocène ont connu un regain d'intérêt au cours des dernières années (Leorri et al., 2012), que ce soit pour la prédiction des futurs changements du niveau marin dans une optique de maîtrise des risques côtiers qu'en tant que jalon pour la calibration des modèles géophysiques. Les variations du NMR résultent d'un processus complexe, déterminées par une combinaison de facteurs variables dans le temps et l'espace. Bien qu'en premier lieu déterminée par le niveau marin " eustatique », découlant de la fonte des inlandsis continentaux après le Dernier maximum glaciaire (DMG), l'histoire du niveau marin relatif d'une région est aussi le produit de facteurs plus locaux (Shennan et al., 2012) ayant dicté le comportement vertical de la zone d'étude durant l'Holocène (isostasie et tectonique). Les processus qui déterminent la qualité de l'enregistrement du NMR dans les séquences sédimentaires, tels que la compaction, les modifications éventuelles des régimes tidaux au cours de la période d'étude, les phénomènes d'érosion et/ou de troncature des dépôts, jouent aussi un rôle majeur dans ces reconstitutions. Considérés comme des facteurs clés nécessaires pour comprendre comment les systèmes sédimentaires côtiers ont autrefois réagi face aux changements de NMR, ces derniers ont fait l'objet de nombreux travaux récents (Shennan et Horton, 2002 ; Edwards, 2006 ; Long et al., 2006 ; Massey et al., $2006 b$; Behre, 2007 ; Vink et al., 2007 ; Horton et Shennan, 2009 ; Bungenstock et Weerts, 2010 ; Baeteman et al., 2011 ; Brain et al., 2011). Si les côtes du nord-ouest de l'Europe ont fait l'objet de nombreuses études portant sur le NMR holocène, la façade atlantique française souffre quelque peu d'un manque d'attention. Dans le Finistère, seules deux études se sont réellement attardées sur le sujet (Morzadec-Kerfourn, 1974 ; Stephan, 2011). Celles-ci font état d'un NMR oscillant, notamment autour de 3000 BP où une baisse pluri-métrique du NMR est constatée par les auteurs. Cette période a été identifiée à l'échelle du nord-ouest de l'Europe comme une période de détérioration du climat (tempétuosité accrue, hiatus importants au sein des séquences sédimentaires ; e.g., Lamb, 1977 ; Long et Hughes, 1995 ; Van Geel et al., 1996 ; Moura et al., 2007), posant ainsi la question de l'authenticité de l'épisode régressif observé.
Dans le cadre d'un programme de recherche portant sur les risques côtiers (ANR COCORISCO), un important travail de terrain a été mené au cours des trois dernières années autour de la péninsule finistérienne. Des dizaines de carottes ont été prélevées avec pour objectif principal l'étude des effets de la paléo-tempétuosité holocène. Par ailleurs, ces données ont pu être utilisées à des fins de reconstitution $d u$ NMR, permettant ainsi de densifier de manière significative les données déjà disponibles sur la région. La Bretagne est un domaine géologique n'ayant pas été directement concerné par les glaciations du DMG. Néanmoins, plusieurs études mettent en lumière le fait que cette région a pu être concernée par le dégonflement du rebond isostatique post-glaciaire lié à la fonte des calottes britanniques et scandinaves (Lambeck, 1997 ; Massey et al., 2008 ; Bradley et al., 2011 ; Leorri et al., 2012 ; Shennan et al., 2012). L'importance de la tempétuosité dans cette région ainsi que les marnages importants complexifient quelque peu la reconstitution des NMR passés. Les carottes ont été collectées en utilisant un carottier à percussion, une tarière à vis (instrumentation BRGM) ou une tarière manuelle. Leurs positions ont été relevées au GPS différentiel et raccordées au système NGF. Les dépôts ont été datés par le radiocarbone (AMS). La moitié des datations a été réalisée sur l'ensemble du sédiment. Pour l'autre moitié, l'échantillonnage s'est attaché à réduire au maximum les possibilités de pollution potentiellement induites par les apports de carbone allochtone, en sélectionnant des fragments végétaux à plus faible potentiel de resédimentation (Gehrels et al., 1996 ; Törnqvist et al., 1998 ; Gehrels, 1999). Les isotopes stables du carbone ont été mesurés en routine lors des mesures $d u{ }^{14} C$. Toutes les dates sont présentées calibrées avec un intervalle de probabilité de $95 \%(2 \sigma)$.

Une approche reposant sur les tourbes de base a été utilisée au travers de cette étude, afin de reconstituer une enveloppe générale des variations du NMR (de l'ordre du millénaire ; Gehrels, 1999). Comme l'ont prouvé un grand nombre de travaux tant sur les côtes européennes (Jelgersma, 1961 ; Van de Plassche, 1982 ; Törnqvist, 1993 ; Denys et Baeteman, 1995 ; Van de Plassche, 1995 ; Beets et Van Der Spek, 2000 ; Shennan et Horton, 2002 ; Makaske et al., 2003 ; Berendsen et al., 2007) que sur d'autres façades océaniques (e.g., Redfield et Rubin, 1962 ; Pirazzoli et Pluet, 1991 ; Gehrels et Belknap, 1993 ; Gehrels et al., 1996 ; Long et al., 1998 ; Törn- 
qvist et al., 2004, 2006), il est maintenant largement accepté que ce type de dépôt représente un témoin particulièrement adapté pour la reconstitution du NMR holocène sur les littoraux de submersion (zones subsidentes). Les tourbes de base ont donc été utilisées comme indicateurs du NMR passé de la manière suivante : lorsque des indices ont permis d'identifier une influence marine à saumâtre dans les dépôts, il a été alors possible de leur appliquer un "indicative meaning », c'est-àdire une relation altitudinale reliant leur milieu de sédimentation au niveau de la mer au moment du dépôt (Shennan, 1986 ; Van de Plassche, 1986 ; Gehrels et al., 1996). Celui-ci a été fixé entre les plus hautes mers astronomiques et les pleinesmers de morte-eau, avec une erreur (nommée "indicative range »; Gehrels et al., 1996) fixée à la moitié de ce rapport. Au contraire, lorsqu'aucun indice n'a permis de déceler une quelconque influence marine, il n'a pas été possible de déterminer l'altitude à laquelle s'est formé le dépôt par rapport au niveau marin. Dans ce cas, l'altitude du dépôt a servi à fixer une limite supérieure maximale ( " high limiting deposits »ou $H L)$ au niveau marin de l'époque.

Du fait de la très faible présence, voire la totale absence de proxys micro-faunistiques dans les dépôts, la détermination du régime de salinité de l'environnement originel de formation des niveaux datés s'est effectuée via l'utilisation conjointe de plusieurs indicateurs. Ceux-ci ont livré notamment des informations sur les formations végétales établies au moment de la mise en place du dépôt. Les isotopes stables $d u$ carbone $\left({ }^{13} \mathrm{C} /{ }^{12} \mathrm{C}\right)$ ont été utilisés sous la forme d'un indicateur nommé " $\delta^{13} \mathrm{C} »$. Celui-ci permet de distinguer entre différentes catégories de plantes suivant le type de photosynthèse $\left(\mathrm{C}_{3}\right.$ ou $\left.C_{4}\right)$ qu'elles effectuent. Par exemple, les valeurs $d u \delta^{13} C$ dans un environnement de slikke sont bien plus élevées que celles obtenues au sein d'une roselière à phragmites. Si cela permet parfois de distinguer clairement des dépôts saumâtres, le plus souvent, le recouvrement des valeurs $d u \delta^{13} C$ fait que cet indicateur doit être utilisé en association avec d'autres. Quelques fois, l'identification des macrorestes végétaux a pu fournir des informations utiles. Les données de M.-T. Morzadec-Kerfourn (1974) ont été actualisées et utilisées de la même façon que nos propres données. Seules les tourbes identifiées comme basales ont été conservées. La détermination de l'environnement original de dépôt des tourbes de base décrites par cet auteur s'est fait sur la base des informations palynologiques telles que présentées dans le manuscrit original. Des marges d'erreurs ont été ajoutées aux données originales $( \pm 50 \mathrm{~cm}$ pour le positionnement vertical du dépôt, recalibration des dates selon le standard utilisé pour nos propres datations).

Six points index et six points limitants ont permis d'obtenir les tendances à long-terme (millénaire) d'évolution du NMR dans le Finistère entre 7500 et 4000 cal. BP. Une remontée globale du NMR de 9,5 $\pm 0,5$ m est observée depuis $7500 \mathrm{cal}$. $B P$. La vitesse de relèvement semble s'infléchir aux environs de 7000 cal. BP, suivant un rythme d'environ 1,3 mm/a jusqu'à $\sim 4500 \mathrm{cal}$. BP. La période entre 6500 et $5000 \mathrm{cal}$. BP demeure mal définie, aucune tourbe de base n'ayant été obtenue pour cette période. De la même façon, aucun point n'a pu être obtenu après 4500 cal. BP avec cette méthode. Nos données montrent une très bonne cohérence avec les données obtenues par P. Stephan (2011) en rade de Brest à partir de l'étude des foraminifères, à l'exception d'un point bas identifié par cet auteur autour de 2800 BP. Ce point fut obtenu à partir d'un dépôt potentiellement issu d'un épisode morphogène ayant pu artificiellement abaisser le niveau de sédimentation (e.g., reprise de sédimentation après un épisode érosif). Nous avons donc considéré que ce point n'était pas représentatif $d u$ NMR de l'époque. L'ensemble des données disponibles, toutes marges d'erreur prises en compte, permet de dresser des tendances claires d'évolution du NMR pour les périodes entre 7500-7000 cal. BP et 7000-3000 cal. BP, avec des taux de remontée respectivement autour de $8 \mathrm{~mm} / \mathrm{a}$ et $1,4 \mathrm{~mm} / \mathrm{a}$. Après 3400 cal. BP, les données de P. Stephan (2011) permettent d'évaluer le taux moyen de remontée à $\sim 0,3 \mathrm{~mm} / \mathrm{a}$. Ces valeurs ne doivent être prises qu'à titre indicatif, des doutes demeurant autour de 6000 et 3000 cal. BP. En effet, à l'heure actuelle, il n'est pas possible d'affirmer que le NMR n'a pas connu des périodes de remontée très lente, voire de stabilisation entre les phases de transgression bien marquées. Ces périodes de fléchissement du rythme de remontée du NMR ont probablement eu des effets importants sur le fonctionnement des systèmes lagunaires et des marais d'arrière-cordon à partir desquels nos données ont été obtenues. Ainsi, nous suspectons que des problèmes de datation, liés par exemple à des remaniements, ont pu venir complexifier la reconstitution du NMR à ces périodes avec ce type de données. Les travaux sont en cours afin d'apporter des données supplémentaires qui permettront sans doute d'arriver à une reconstitution fiable $d u$ NMR holocène pour l'ouest de la Bretagne.

\section{Introduction}

Recent years have seen a revival of interest in the use of relative sea-level (RSL) curves for a wide range of applications (Leorri et al., 2012) from the prediction of future sealevel changes in coastal risk assessment issues to the finetuning of geophysical Earth rheology models. The behaviour of coastal systems in reaction to Holocene sea-level rise is a complex process. To derive RSL (taken here as the relative altitude of past sea-level relative to a present reference level) changes from observations is hence a complex challenge. Though primarily determined by eustasy, RSL changes result from the combination of many interdependent processes. As clearly stated by I. Shennan et al. (2012), sea-level changes for a precise geographical location and epoch result from the sum of the following factors: (A) Eustatic sea-level, which varies in time following the melting history of ice-caps ("ice-equivalent" eustasy), changes in the ocean-basin volume ("tectono-eustasy"), and changes in the ocean mass-water distribution. (B) Isostatic processes affecting the vertical behaviour of the lithosphere during the post-glacial period of study, dependent on the geographical position relative to the past extension of ice-caps (glacioisostasy) and of the loading by the water-charge (hydroisostasy) during transgression. The sum of (A) and (B) produces the global trend in the RSL rise. Along with those major factors must be added: (C) Tectonic activity expressed 
by vertical displacements that could have occurred during the considered period. These latter displacements can explain rapid jumps in the RSL signal and must be looked for in regions known as tectonically active during the Holocene (Fouache, 2006; Morhange et al., 2006; Gandouin et al., 2007). In addition to these factors are superimposed more local effects, which bear direct consequences on the way the sedimentary sequences record the RSL changes: (D) Local effects are likely to control the sedimentary record and, as a consequence, the preservation and the present-day restitution of Holocene RSL. In fact, locally, sedimentary sequences undergo syn- and/or post-deposit processes: major local effects are traditionally considered as being the compaction of the deposits (effect of post-depositional consolidation), lowering the original altitude of a considered unit, and thus the RSL corresponding points), and the changes in tidal regime (leading to an alteration of the sea-level indicative meaning, which is derived from the present day tidal regimes). (E) Finally, I. Shennan et al. (2012) consider an additional factor regrouping other unspecified, random and hard-to-quantify factors influencing the RSL reconstruction at a given site. We propose here that erosion truncations of sedimentary sequences must be considered as one of the major components of this additional factor of the RSL equation, considering the importance of its probable impacts on both the indicative meaning of the studied sedimentary sequences and on the compaction processes. Several recent works have attempted to sort out the relative importance and the timing of local parameters (D) and (E), considering them as keys to a better understanding of the response of coastal systems to past sealevel rises (Shennan and Horton, 2002; Edwards, 2006; Long et al., 2006; Massey et al., 2006b; Behre, 2007; Vink et al., 2007; Horton and Shennan, 2009; Bungenstock and Weerts, 2010; Baeteman et al., 2011; Brain et al., 2011).

Northwestern European coasts have been the subject of several works dealing with Holocene RSL variations (e.g., among many others: Fairbridge, 1961; Ters, 1973; Morzadec-Kerfourn, 1974; Ters, 1986; Van de Plassche, 1991; Denys and Baeteman, 1995; Long et al., 1996; Lambeck, 1997; Shennan and Horton, 2002; Massey et al., 2006a; Edwards and Horton, 2007; Massey et al., 2008; Bungenstock and Schäfer, 2009; Stephan, 2011; Leorri et al., 2012). In comparison with British coasts, French Western Atlantic and Channel coasts have been the subjects of fewer studies (Delibrias and Guillier, 1971; Ters, 1973; Morzadec-Kerfourn, 1974; Van de Plassche, 1991; Morzadec-Kerfourn, 1995; Lambeck, 1997; Clavé et al., 2001; Stephan, 2011; Leorri et al., 2012). In the Finistère region, only two authors really focused on this subject (Morzadec-Kerfourn, 1974, 1995; Stephan, 2011). Both authors proposed that plurimetric oscillations in RSL curves could have taken place $c a .3000$ cal. BP. However, these works were conducted in two areas of relatively limited extension and produced curves based on a limited number of sea-level index points (a total of around fifteen dates for each of the two studies). Such limitations make inter-comparisons between sites difficult and hence can impair the deciphering of local processes in the RSL signal. Finally, the period ca. 3000 cal. BP was generally identified around northwestern European coasts as a period of increased storminess, which has caused strong perturbations and large hiatuses in the sedimentary sequences (Lamb, 1977; Long and Hughes, 1995; Van Geel et al., 1996; Moura et al., 2007). Hence, we consider that obtaining a reliable and high-frequency sea-level curve for Western-Brittany is of prime interest, as it will contribute both to the understanding of the coastal processes, which may be the consequences of the sea-level variations and, at a broader scale, the comprehension of post-glacial isostatic history of NorthWestern Europe.

Within the framework of a coastal risk assessment research program (ANR COCORISCO, French National Research Agency), an extensive fieldwork has been conducted during the last three years all around the Finistère peninsula (Western part of Brittany, France). Tens of cores and drillings have been carried out in sites of various sedimentary environments and expositions. Whilst the principal objective of this fieldwork was to obtain data that would allow the study of the palaeostorminess during the Holocene, the sampled sedimentary sequences could also be fruitfully interpreted to derive RSL data. This allowed us to densify significantly the Holocene RSL data available for this region and also to reassess and update the results of M.-T. Morzadec-Kerfourn (1974) and P. Stephan (2011). This paper is the first step of an effort in updating Western Brittany RSL data. The first part will briefly outline the geological context of the study area, considering possible internal geodynamic controls on vertical crustal movements that could have occurred during the period of investigation. The methodology we used to reconstruct RSL changes will be described in a second part, with particular attention paid to possible errors that may occur at various stages of the reconstruction process. In order to allow comparisons between previously published interpretations and our own results, derived from an extended new data set, the same methodology has been applied to both to new and previously published data. Finally, the ongoing need for a better deciphering of both local and regional effects for the fine-tuning of the Holocene RSL history is exemplified and the possible behaviour of coastal systems in reaction to the proposed Holocene RSL rise is briefly evaluated.

\section{The study area}

This paper presents new stratigraphic data and RSL data collected along the coast of the Finistère peninsula (Western Brittany, France). As stated above, the rationale for the choice of site locations primarily resulted from the objectives of the COCORISCO program, which privileged sites showing very different exposures to major forcing agents (large tidal ranges, storms swells), resulting in diverse sedimentation conditions (in terms of sediment supply, accumulation and preservation). This largely explains why the selected sites are not always the most favourable to derive a long and continuous RSL signal. Nevertheless, we believe that these widespread and diverse site locations and types can be profitable to improve the regional representation of reconstructed RSL. Moreover, such 
Fig. 1 - Location maps of the study area. Numbers refer to sites presented in the text. 1: Kerlouan-Guissény; 2: Landeda-Tariec; 3: Porsmilin; 4: Treffiagat; 5: Kermor-Tudy; 6 : Guidel. Letters A to $D$ refer to sites from which sedimentary sequences were re-assessed from M.-T. Morzadec-Kerfourn (1974). A: Plouescat-Porsguen. B: Ploudalmezeau-Treompan. C: Argenton. D: Trézien. Letters $\mathrm{H}$ to $\mathrm{J}$ refer to sites studied by P. Stephan (2011) in the Bay of Brest. H: Porzguen marsh. I: Troaon marsh. J: Arun marsh.

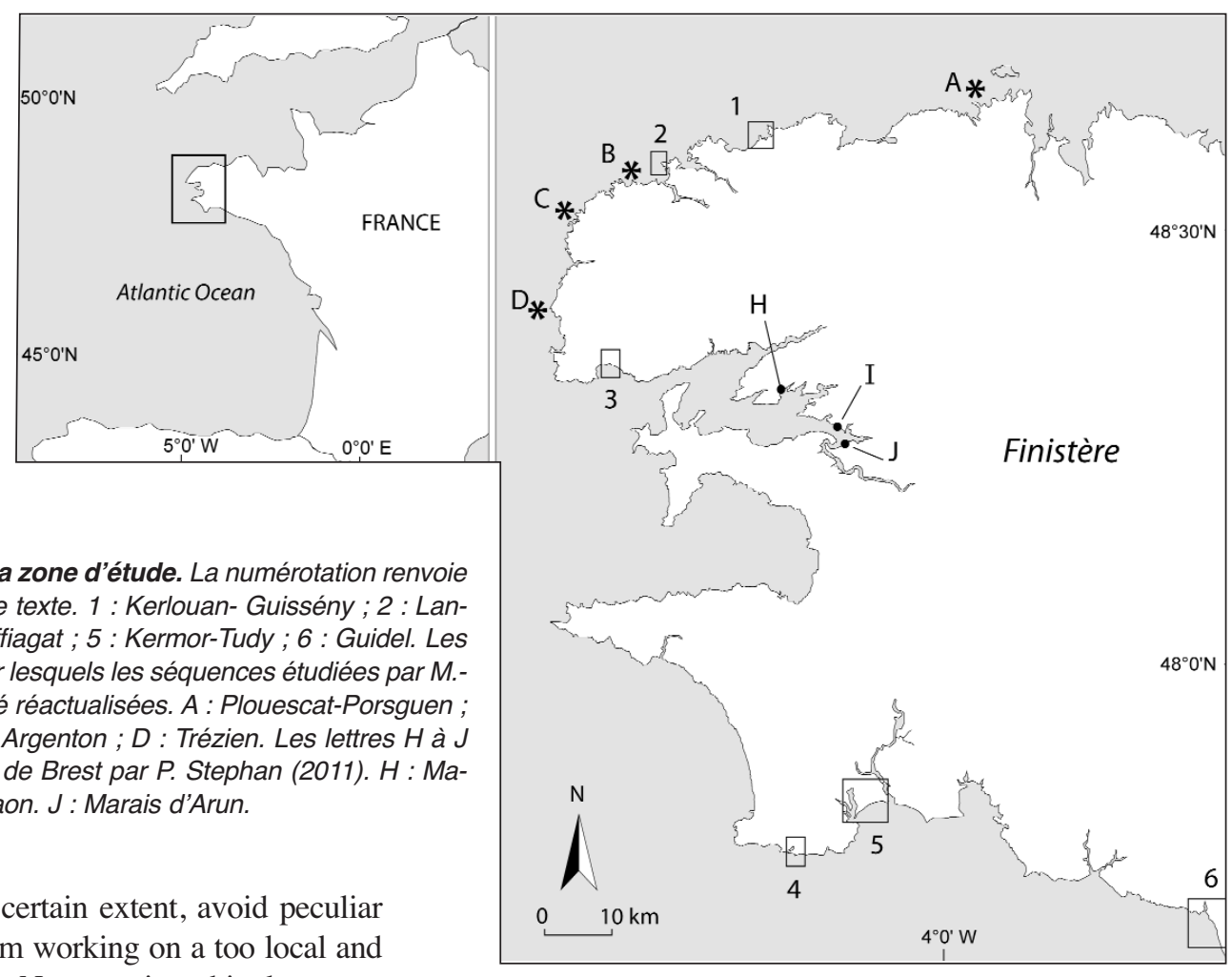

a choice of the sites may, to a certain extent, avoid peculiar RSL biases that could result from working on a too local and geographically restricted dataset. New stratigraphic data were collected on eight sites distributed all along the Finistère peninsula: Kerlouan-Guissény and Landeda in the North Finistère, Porsmilin in the central part of the peninsula, and Treffiagat, Kermor-Tudy and Guidel in the southern part (fig. 1).

\section{Geological and geodynamic setting}

Geological and geodynamic factors, which control the possible vertical movements of any particular crustal area, are of prime importance in RSL reconstitutions and can be considered as the primary producers of RSL histories. They can be divided as follows: (i) Long-term geological evolutions, typically spanning over tens of thousands to millions years, (ii) Holocene glacio- and hydro-isostatic processes (from a few hundreds to a few thousands of years), and (iii) short-term tectonic events (a few days). As geological processes are concerned, the following will be considered as the basis of this study and be used for the comparison of our data with southern-UK works. On a long timescale, Brittany is considered to subside step-wise since the opening of the Bay of Biscay during Early Cretaceous (Evans, 1990), as a passive margin and as a flank of the Western Channel graben. Globally, long-term subsidence has been evaluated between $0.02 \mathrm{~mm} / \mathrm{a}$ and $0.04 \mathrm{~mm} / \mathrm{a}$ since the Eocene for the northern coasts and western/southern coasts of Brittany, respectively (Bonnet et al., 2000). The regional subsidence can be considered as negligible at the timescale of the Holocene $(\sim 40 \mathrm{~mm}$ for the last 10,000 years), with respect to the amplitude of the RSL changes we consider.

As underlined in the introduction, estimations of the amplitude of potential isostatic adjustments undergone by Western Brittany, as a consequence of the melting of the North-western Europe and North hemisphere ice caps still lack precision,

awaiting specific numerical studies and geophysical models, well-constrained by local high-quality and dense RSL information. During the Last Glacial Maximum, Brittany occupied a peripheral position with respect to the British Ice Sheet (BIS). The maximum extent of the BIS reached the Scillies (Scourse et al., 1990; Scourse 1991) and had already retracted before $17 \mathrm{ka}$ as evidenced from the dating of loess along the coasts of Wales (Wintle, 1981). Recent studies, conducted in South-Western UK (Massey et al., 2008; Bradley et al., 2011; Shennan et al., 2012), consider that this latter region must have been under the joint influence of both the BIS forebulge and long wavelength isostatic responses related to Fennoscandia ice-sheet. E. Leorri et al. (2012) performed modelling work from RSL datasets around the Bay of Biscay and conclude that a north-south increasing RSL gradient exists between Brittany and Portugal. As primarily proposed by K. Lambeck (1997), this would confirm that vertical landmotions induced by the subsidence of a peripheral bulge, associated to the melting of Eurasian Ice-Sheets, have had (and maybe still have) noticeable effects at least as far south as the southern Bay of Biscay. While both (i) the position, size and migration timing of the forebulge apex remain uncertain and (ii) the role of the deep faults bordering the Channel and Western Approaches domains during the Holocene is still questionable, it appears that Brittany could have also been concerned by such glacio-isostatic vertical movements. Nonetheless, modelling work performed by E. Leorri et al. (2012) has to be taken with caution as Brittany RSL reconstruction on which are based these modelling are rather old and did not received proper error re-assessment. Furthermore, this study got RSL data from different regions confusedly mixed up from their original locations. In fact, a careful inspection of the datasets reveals that a site named 


\begin{tabular}{|c|c|c|c|c|c|c|c|c|c|}
\hline no. & Location & Latitude & Longitude & $\begin{array}{c}\text { Tidal range } \\
\text { (in m) }\end{array}$ & $\begin{array}{c}\text { HAT } \\
\text { (in m NGF) }\end{array}$ & $\begin{array}{c}\text { MHWST } \\
\text { (in m NGF) }\end{array}$ & $\begin{array}{c}\text { MHWNT } \\
\text { (in m NGF) }\end{array}$ & $\begin{array}{c}\text { MTL } \\
\text { (in m NGF) }\end{array}$ & $\begin{array}{c}\text { MLWST } \\
\text { (in m NGF) }\end{array}$ \\
\hline A & Plouescat & $48^{\circ} 39^{\prime} \mathrm{N}$ & $4^{\circ} 12^{\prime} \mathrm{W}$ & 7.43 & 5.10 & 4.26 & 2.49 & 0.67 & -3.17 \\
\hline 1 & Guisseny & $48^{\circ} 38^{\prime} 14 \mathrm{~N}$ & $4^{\circ} 23^{\prime} 56 \mathrm{~W}$ & 7.52 & 4.74 & 4.06 & 2.36 & 0.62 & -3.46 \\
\hline \begin{tabular}{c} 
2 \\
\hline
\end{tabular} $\begin{array}{c}\text { Landeda- } \\
\text { Tariec }\end{array}$ & $48^{\circ} 36^{\prime} 10 \mathrm{~N}$ & $4^{\circ} 36^{\prime} 30 \mathrm{~W}$ & 6.75 & 4.57 & 3.78 & 2.13 & 0.46 & -2.97 \\
\hline B & $\begin{array}{c}\text { Ploudal.- } \\
\text { Treompan }\end{array}$ & $4^{\circ} 34^{\prime} \mathrm{N}$ & $4^{\circ} 40^{\prime} \mathrm{W}$ & 6.6 & 4.54 & 3.69 & 2.11 & 0.46 & -2.91 \\
\hline C & Argenton & $4^{\circ} 31^{\prime} \mathrm{N}$ & $4^{\circ} 45^{\prime} \mathrm{W}$ & 6.47 & 4.48 & 3.68 & 2.08 & 0.47 & -2.79 \\
\hline $\mathrm{D}$ & Trezien & $4^{\circ} 25^{\prime} \mathrm{N}$ & $4^{\circ} 47^{\prime} \mathrm{W}$ & 6.08 & 4.32 & 3.51 & 1.96 & 0.48 & -2.57 \\
\hline 3 & Porsmilin & $48^{\circ} 21^{\prime} 19 \mathrm{~N}$ & $4^{\circ} 40^{\prime} 49 \mathrm{~W}$ & 5.55 & 3.99 & 3.17 & 1.67 & 0.39 & -2.38 \\
\hline 4 & Treffiagat & $47^{\circ} 47^{\prime} 29 \mathrm{~N}$ & $4^{\circ} 15^{\prime} 54 \mathrm{~W}$ & 4.20 & 3.16 & 2.66 & 1.56 & 0.50 & -1.54 \\
\hline 5 & Kermor-Tudy & $4^{\circ} 51^{\prime} 54 \mathrm{~N}$ & $4^{\circ} 07^{\prime} 37 \mathrm{~W}$ & 4.20 & 3.09 & 2.45 & 1.35 & 0.41 & -1.75 \\
\hline 6 & Guidel & $47^{\circ} 45^{\prime} 44 \mathrm{~N}$ & $3^{\circ} 30^{\prime} 10 \mathrm{~W}$ & 4.15 & 2.78 & 2.23 & 1.18 & 0.17 & -1.92 \\
\hline
\end{tabular}

Tab. 1 - Present-day tidal ranges on studied sites. HAT (Highest Astronomical Tide), MHWST (Mean High Water Spring Tides), MHWNT (Mean High Water Neap Tides), MTL (Mean Tide Level), MLWST (Mean Low Water Spring Tides). Letters and Numbers in the first column refer to fig. 1.

Tab. 1 - Marnages actuels sur les sites d'étude. HAT (plus hautes mers astronomiques), MHWST (pleines mers de vive-eau moyenne), MHWNT (pleines mers de morte-eau moyenne), MTL (marée moyenne), MLWST (basses mers de vive-eau). Les lettres et numéros figurant dans la première colonne renvoient aux sites tels que présentés dans la fig. 1.

"Saint-Marc" is taken by the authors to be in south-Brittany, while original data from M. Ters (1973) mention "Côtes-duNord" which is situated in north-Brittany. Hence, in absence of more precise work regarding this problem, the question of the Holocene vertical behaviour of the Brittany region towards the glacio-isostatic effects remains suspended.

The hydro-isostatic vertical movement induced by the loading of the Atlantic continental shelf and the Channel platform during the Holocene transgression can be considered as of comparable amplitude between South-Western UK and Brittany, considering the similar ages and, therefore, the comparable rigidities of the crust of the two regions. Finally, neotectonics is generally considered to have been inactive in Brittany over the study period.

\section{Morphodynamic setting}

Due to the direct opening of the region towards the Atlantic Ocean, the Finistère peninsula is the part of Brittany most exposed to dominant storm winds and swells. These exposure conditions result in (i) a majority of sand-dominated sedimentary environments and (ii) a rather limited number of protected low-energy environments susceptible to have recorded continuously the RSL history. As revealed by the several erosion surfaces observed within our sequences, impacts of storminess during the Holocene have heavily disturbed and discontinued mid- to late-Holocene sedimentary sequences along the Finistère coasts. As this study principally focuses on basal deposits, this will not bear consequences on the results presented in this paper. The possible role played by storminess and sedimentary hiatuses will be discussed when comparing our results to other studies, which use non-basal deposits to derive RSLs.

\section{Tidal setting}

Tidal settings are of major importance in RSL studies. In fact, most RSL reconstructions are based on the study of the altitudinal zonation of intertidal indicators (whether biological or sedimentological) with respect to a reference tidal level (such as the Mean High Water Spring Tide, MHWST, or the Mean Sea Level, MSL). Hence, by determining the vertical range in which an indicator could have been emplaced (the "indicative range"), the tidal range of a studied site will partially determinate the accuracy of past RSLs. While micro-tidal regions, such as the Mediterranean Sea, allow well-constrained and precise indicative ranges (pluricentimetres to decimetre scale), macro-tidal conditions, such as the ones encountered along the coast of Brittany, can introduce larger errors in RSL reconstitutions (pluri-decimetres to metre-scale error terms). Moreover, potential changes in the tidal ranges during the Holocene could have resulted in supplementary errors in past RSL reconstitutions, by over- or under- estimating the indicative meaning. Indeed, as stated by W.R. Gehrels et al. (1995), many RSL studies are based on high-tide indicators. Thus, changes in tidal ranges through time may cause the reconstructed RSL curve to differ from the "true" MSL curve (as termed in Gehrels, 1999). The Finistère peninsula is concerned by macro- to meso-tidal conditions, with tidal ranges globally decreasing from north to south (tab. 1). Variability in the tidal ranges between the different study sites will be taken into account in the determination of the indicative ranges error terms (see methodology). Evaluation of possible changes in the tidal ranges and regimes during the study period is beyond the scope of this paper. Possible implications of these changes will be discussed in the quantification of the RSL reconstruction error-terms. 


\section{RSL reconstruction from Holocene basal deposits: Methodological background}

\section{Sea-level index points}

RSL reconstitutions generally rely on the acquisition of Sea-Level Index Points (SLIPs), or Sea-level Indexes (SLIs), which characterise the altitudinal position of a chosen tide level (e.g., the Mean High Water Spring Tide, which will be the reference throughout this work) relative to its modern altitude, considered as the zero reference level. As stated by W.R. Gehrels (1999), the vertical determination of a SLIP at time $(t)$ can be expressed as:

$\operatorname{SLIP}(t)=\mathrm{H}-\mathrm{D}-\mathrm{I}(t)+\mathrm{T}(t)-\mathrm{L}+\mathrm{A}(t)$

where $\mathrm{H}$ is the height of the coring station from which the indicator sample is taken relative to the modern tidal altitudinal reference, $\mathrm{D}$ is the depth of the sample in the core, $\mathrm{I}(t)$ is the "indicative meaning", i.e. the relation between the altitude of the original deposition environment of a given sample and the palaeo-tidal reference level (e.g., MHWST) at the time of deposition (Shennan, 1986; Van de Plassche, 1986; Gehrels et $a l ., 1996), \mathrm{T}(t)$ represents the potential changes in tidal amplitude between time $(t)$ and present, L stands for the compaction induced by the coring-process as evaluated in the field and $\mathrm{A}(t)$ is the auto-compaction undergone by the sample after deposition. If an "indicative meaning" cannot be properly assessed for a deposit, then a status of "limiting point" is generally attributed to the sample. Limiting points can help to constraint former RSL positions, and are defined as follow: "High-Limiting" (HL) or "Low-Limiting" (LL) whether the deposit is identified to have formed at an unquantified altitude above or below the reference tidal level, respectively. To reach some reliability and precision, RSL reconstructions must rely on a combination of methods, as no single method is considered to be unequivocal. The methods used in this study, or in re-assessed previous works, are detailed below in some details. For a general view on RSL reconstruction methods, readers can refer to I. Shennan (2007), R.J. Edwards (2007), and to the publications of the UNESCO-IGCP projects (e.g., projects no. $61,274,588)$.

\section{Holocene basal peats}

Basal peats have been extensively used in Holocene sealevel studies, especially in northwestern Europe (e.g., Jelgersma, 1961; Van de Plassche, 1982; Törnqvist, 1993; Denys and Baeteman, 1995; Van de Plassche, 1995; Beets and Van Der Spek, 2000; Shennan et al., 2000; Shennan and Horton, 2002; Makaske et al., 2003; Berendsen et al., 2007), and also along other oceanic facades (e.g., Redfield and Rubin, 1962; Pirazzoli and Pluet, 1991; Gehrels and Belknap, 1993; Gehrels et al., 1996; Long et al., 1998; Törnqvist et al., 2004, 2006). As underlined by T.E. Törnqvist et al. (2004), this approach is particularly suitable for reconstructing RSL history along submerging coastlines and has widely proven its accuracy to provide consistent RSL records. Indeed, the submergence of the Pleistocene glacial plains by the coastal
Ground Water Level (GWL) wedge during post LGM sealevel rise provoked a decrease of the drainage and subsequently the formation of freshwater to brackish marsh environments belts environments, in which peat accumulated (Baeteman et al., 1999; Vink et al., 2007). A landward and upward progression of the peat layers marks the emplacement of the rising water level. Moreover, basal peats directly overlay the geological substrate or, more often, Pleistocene silty-loess of fluvial deposits, traditionally considered as having experienced negligible compaction during the Holocene. The altitude of the basal peats hence can be used as a reliable marker of RSL rise.

Nonetheless, the representativeness of basal peats as RSL indicators has been regularly discussed. Several limitation problems have been identified in their use as sea-level indicators. The unclear relations between the GWL and sea level may cause errors in RSL reconstructions. As identified by O. Van de Plassche $(1982,1995)$, distortions of the tidal wave in large deltaic plain environments ("flood-basin effect") or in estuarine settings (Fairbridge, 1961; Vink et al., 2007), can lead to under- or over-estimation of the RSL. The importance of local continental hydrological and drainage conditions can also be invoked. In order to avoid these errors, some authors recommended that only basal peats should be used as an upper RSL limit (Edwards, 2007; Vink et al., 2007). Others (Gehrels et al., 1996; Gehrels, 1999; Törnqvist et al., 2004) advocated that basal peats remain usable as SLIPs if a clear relationship between their original deposit environment and sea level can be established (i.e., from the presence of indicators undoubtedly attesting that peat formed in an environment submitted to brackish to saline conditions). Only in this case, basal peats can be considered to have formed between MSL and HWST and can be used as SLIPs (Van de Plassche, 1982; Törnqvist et al., 2004).

The salinity regime of the original deposit environments can be assessed by several methods. Microfossils, such as diatoms or foraminifera, are considered to be the most reliable method available to achieve such an aim. When present, microfossils attest at least a minimal influence of marine conditions (Gehrels, 1999). The importance of this influence can be deduced by the determination of species assemblages. Unfortunately, foraminifera were absent or very scarce in the samples we studied, probably due to their limited potential of conservation or to unfavourable living conditions (sand dominated deposits). Micro- and macro-faunal indicators can also provide useful information. Plant communities obey a vertical zonation with respect to ecological factors (among which the frequency of inundation is dominant) and thus can be used as indicators to determine the salinity regimes. Pollen assemblages have been widely used in Holocene palaeo-environmental studies, as a proxy for reconstructing past landscapes and anthropogenic activity. It also revealed capacities to decipher between different sedimentary environments, especially in intertidal mud-dominated environments (such as mudflats and salt-marshes), where strong environmental gradients exist. Transitions between marine and freshwater dominated environments can be identified following the succession of dominating plant species. 
Stable carbon isotope ratios $\left({ }^{13} \mathrm{C} /{ }^{12} \mathrm{C}\right)$ have been less often used to recognise salt-marsh environments within organic sedimentary sequences (Chmura and Aharon, 1995; Gehrels et al., 1996; Törnqvist et al., 2004; Wilson et al., 2005; Lamb et al., 2006, 2007; Kemp et al., 2010). The stable carbon isotope ratio ${ }^{13} \mathrm{C} /{ }^{12} \mathrm{C}$ is noted $\delta^{13} \mathrm{C}$, and expressed in parts per thousand PDB (\%o PDB) relative to the reference ${ }^{13} \mathrm{C}$ value (standard determined from a Cretaceous marine fossil named Pee Dee Belemnite, "PDB"). Mudflat/lowmarsh and high-marsh/supratidal specific plant species were found to follow different photosynthetic pathways (termed " $\mathrm{C}_{3}$ " and " $\mathrm{C}_{4}$ "), inducing very different $\delta^{13} \mathrm{C}$ imprints in the surface sediment on which those latter grow. Unfortunately, values in $\delta^{13} \mathrm{C}$ sometimes largely overlap and therefore preclude using $\delta^{13} \mathrm{C}$ directly as a 'true' RSL proxy (Wilson et $a l ., 2005)$. This ratio has nevertheless proved its ability to clearly decipher between low-marsh and high-marsh environments. Thus, the $\delta^{13} \mathrm{C}$ stable carbon isotope ratio can help to provide qualitative data about the depositional environment of radiocarbon-dated samples (Wilson et al., 2005; Lamb et al., 2006, 2007; Kemp et al., 2010), especially if associated with other indicators (foraminifera, diatoms, $\mathrm{C} / \mathrm{N}$ ratio). T.E. Törnqvist et al. (2004) used $\delta 1^{3} \mathrm{C}$, together with the study of plant remains, to determine the salinity regime of basal peats found in the Mississippi delta, and consequently to determine if these basal peats could be used as reliable markers of past RSL values. The same approach has been followed in this study.

\section{Methods}

\section{Corings and drillings}

Field data were collected by three techniques: corings (using an Eijkelkamp $60 \mathrm{~mm} \varnothing$, hand-held and motor-driven percussion corer), screw drillings (using BRGM vehicle, French Research Agency for Geology and Mines) and handauguring (3-cm diameter/1-m long Eijkelkamp gouge). Cores positions were surveyed using a Trimble Differential Global Positioning System (DGPS). All locations were tied to geo-referenced IGN (French National Geographic Institute) benchmarks and levelled with respect to the NGF datum (French levelling datum, tied to the present MSL in Marseille, France). Possible deformations of the sequences during the coring stage (e.g., compaction induced by percussion corings) were measured in the field and taken into account in the vertical positioning of the samples. Percussion cores (recovered in 1-m long plastic tubes) were cut in half cylinders and sealed by plastic film. Screw-drillings and auguring samples were kept in sealed plastic bags. All were stored at +4 ${ }^{\circ} \mathrm{C}$ to slow down desiccation and oxidation of the deposits.
Deposits were rapidly described by a litho-microstratigraphic study, in terms of grain size, colour (Munsell color chart), organic content, and characterisation of macrofossils. Particular attention was paid to identify possible reworked levels or erosion surfaces, as these define morphogenic active periods and can give hints on subsequent potential problems in sample dating. Sampling was performed with a $5-\mathrm{cm}$ mean spacing and adapted to the complexity of the sequences. Grain size was measured after destruction of organic material with a solution of hydrogen peroxide in each sample for the $<1-\mathrm{mm}$ fraction with the help of a Malvern Mastersizer 2000 laser analyser. The size of the grains coarser than $1 \mathrm{~mm}$ was analysed by sieving.

AMS radiocarbon dates were performed at the "Laboratoire de Mesure du Carbone 14" (Gif-sur-Yvette) and at the Poznan Radiocarbon Laboratory (Poland). Half of the new dates presented here were dated from bulk deposits (Guisseny cores). Other dated material was sampled with care in order to minimise sources of carbon pollution: in situ material was always preferred to potentially reworked material, such as charcoals or drifted wood. When present, plant remains were preferred as their fragility reduces the potential of re-deposition (Gehrels et al., 1996; Törnqvist et al., 1998; Gehrels, 1999). Stable carbon isotope $\left(\delta^{13} \mathrm{C}\right)$ was routinely measured for all the samples dated at the Gif-sur-Yvette laboratory. Calibration was performed with the Calib 6.0 software, using IntCal09 calibration curve (Reimer et al., 2009). All dates in this study are presented in calibrated age BP, with a $2-\delta(95 \%)$ probability confidence interval (tab. 3 and tab. 4).

\section{Stratigraphy}

Sampled basal peats, lying at the basis of the Holocene sedimentary sequences we sampled, were generally found lying on a thin Pleistocene silt layer resting either directly on the weathered basement or, more often, on a mixed silt and gravel formation. This layer could either consist of a periglacial loess formation (Monnier, 1973; Hallégouët and Van Vliet, 1986) or of an inter-bedded lacustrine mud layer formed by the hampered drainage during the RSL rise. Those units generally progressively evolve towards an organic rich silt layer, which is interpreted as the response to the pro-

\begin{tabular}{|c|c|c|}
\hline & This study & $\begin{array}{c}\text { Re-assessment of } \\
\text { M.-T. Morzadec-Kerfourn (1974) }\end{array}$ \\
\hline Percussion coring & $\varnothing$ & $\varnothing$ \\
\hline Screw-drilling & $\pm 20 \mathrm{~cm}$ & $\varnothing$ \\
\hline Hand-auguring & $-2 \mathrm{~cm} / \mathrm{m}$ depth & $\pm 50 \mathrm{~cm}$ \\
\hline Levelling & $\pm 2 \mathrm{~cm}$ & $\varnothing$ \\
\hline Present tidal frames & $\pm 5 \mathrm{~cm}$ when estimated from distant tidal references \\
\hline Indicative ranges & (HAT-MHWNT)/2 & (HAT-MHWNT)/2 \\
\hline
\end{tabular}

Tab. 2 - Errors terms used in RSL reconstruction.

Tab. 2 - Marges d'erreurs utilisées dans la reconstitution du niveau marin relatif. 


\begin{tabular}{|c|c|c|c|c|c|c|c|c|c|}
\hline 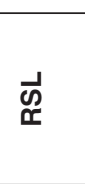 & & $\begin{array}{l}\bar{m} \\
\dot{+1} \\
8 \\
0 \\
\dot{+}\end{array}$ & $\begin{array}{l}\stackrel{0}{9} \\
+1 \\
+1 \\
8 \\
0 \\
1\end{array}$ & $\begin{array}{l}\hat{N} \\
+1 \\
+1 \\
0 \\
\\
1\end{array}$ & $\begin{array}{l}\hat{N} \\
\overline{+} \\
+1 \\
\stackrel{0}{O} \\
\varphi \\
1\end{array}$ & 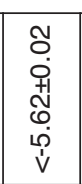 & $\begin{array}{l}\hat{0} \\
\dot{0} \\
+1 \\
\dot{+} \\
\dot{P} \\
\dot{v}\end{array}$ & $\begin{array}{l}\text { Ñ } \\
\stackrel{+}{0} \\
+1 \\
\stackrel{+}{o} \\
\dot{+} \\
\dot{v}\end{array}$ & $\begin{array}{l}\text { N } \\
\dot{0} \\
+1 \\
\dot{0} \\
\dot{0} \\
\dot{v}\end{array}$ \\
\hline 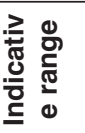 & $\begin{array}{l}\varepsilon \\
. \subseteq\end{array}$ & $\stackrel{\circ}{\leftarrow}$ & $\stackrel{\overbrace{}}{\leftarrow}$ & $\stackrel{\circ}{\check{r}}$ & $\underset{\stackrel{N}{\sim}}{\stackrel{N}{r}}$ & & & & ' \\
\hline 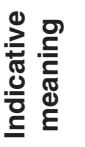 & $\begin{array}{l}\varepsilon \\
. \subseteq\end{array}$ & $\begin{array}{l}\text { Nิ } \\
\text { î. }\end{array}$ & $\begin{array}{l}\text { Nิ } \\
\text { i̊ }\end{array}$ & 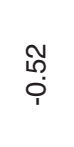 & $\begin{array}{l}\text { O̊. } \\
\text { : }\end{array}$ & & ' & & ' \\
\hline$\stackrel{u}{\stackrel{u}{2}}$ & & $\stackrel{\varrho}{\bar{\varpi}}$ & $\stackrel{\triangleq}{\bar{\Xi}}$ & $\stackrel{\varrho}{\bar{\rho}}$ & $\stackrel{\varrho}{\bar{\Xi}}$ & $\overrightarrow{\vec{x}}$ & $\overrightarrow{\underline{I}}$ & $\overrightarrow{\underline{x}}$ & $\overrightarrow{\underline{I}}$ \\
\hline $\begin{array}{l}\frac{0}{2} \\
\frac{9}{50} \\
0 \\
\frac{0}{10} \\
\frac{10}{10}\end{array}$ & $\begin{array}{l}\stackrel{0}{a} \\
a \\
\circ \\
\stackrel{\circ}{\subseteq}\end{array}$ & ্ָঠ & 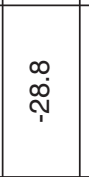 & 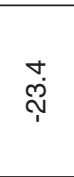 & $\begin{array}{l}\stackrel{\leftrightarrow}{0} \\
\stackrel{\leftrightarrow}{\Lambda}\end{array}$ & $\overline{\grave{T}}$ & & & \\
\hline 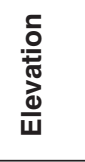 & 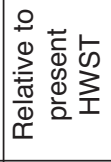 & فִ & $\begin{array}{l}\stackrel{\infty}{\circ} \\
\stackrel{\rho}{\rho}\end{array}$ & $\stackrel{\infty}{\stackrel{\infty}{\leftrightarrow}}$ & $\stackrel{\infty}{\stackrel{\infty}{i}}$ & 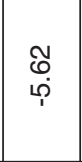 & $\underset{\dot{\rho}}{\bar{\rho}}$ & $\begin{array}{l}\stackrel{+}{O} \\
\dot{i}\end{array}$ & זי \\
\hline 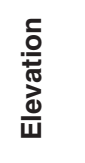 & $\begin{array}{l}\frac{u}{N} \\
\sum \\
\varepsilon \\
.\end{array}$ & $\frac{n}{\stackrel{1}{r}}$ & مَّ & $\begin{array}{l}\text { ஸ̂. } \\
\stackrel{P}{P}\end{array}$ & $\stackrel{\leftrightarrow}{\stackrel{P}{P}}$ & \ٌ & $\begin{array}{l}\stackrel{2}{\circ} \\
\stackrel{0}{1}\end{array}$ & 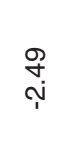 & $\stackrel{\substack{\infty \\
i}}{\stackrel{0}{0}}$ \\
\hline 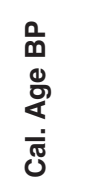 & 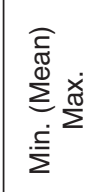 & 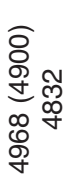 & 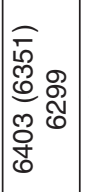 & 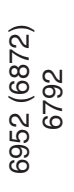 & 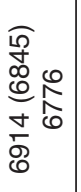 & $\begin{array}{ll}\widehat{0} & \\
0 & \\
0 & 0 \\
0 & 0 \\
0 & 0 \\
0 & 0\end{array}$ & 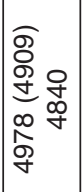 & 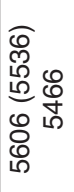 & 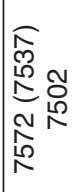 \\
\hline 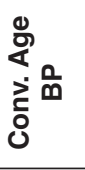 & 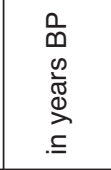 & 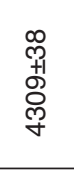 & 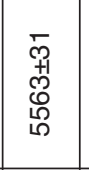 & 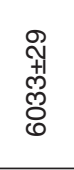 & $\begin{array}{l}\stackrel{\infty}{\dddot{1}} \\
\stackrel{+}{8} \\
\stackrel{0}{0}\end{array}$ & $\begin{array}{l}0 \\
09 \\
10 \\
10 \\
0 \\
0\end{array}$ & 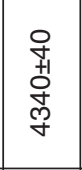 & 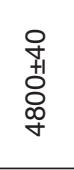 & $\begin{array}{l}\text { O } \\
+1 \\
0 \\
0 \\
0 \\
0\end{array}$ \\
\hline 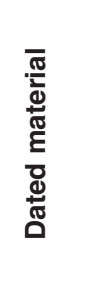 & 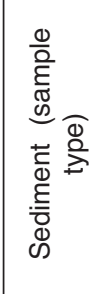 & 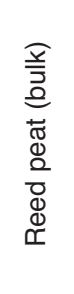 & 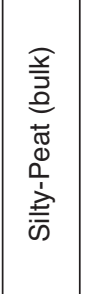 & 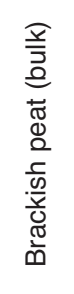 & 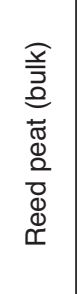 & 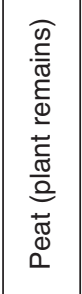 & 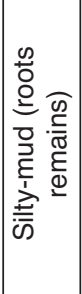 & 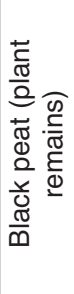 & 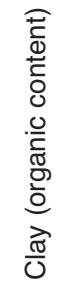 \\
\hline \multicolumn{2}{|c|}{$\begin{array}{l}0 \\
0 \\
0 \\
\text { ฮँ }\end{array}$} & $\begin{array}{l}\overline{0} \\
\frac{1}{0} \\
\frac{1}{\grave{c}} \\
\stackrel{9}{د}\end{array}$ & 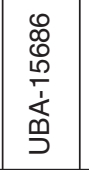 & $\begin{array}{l}8 \\
0 \\
\frac{1}{0} \\
\frac{1}{1} \\
\frac{1}{9}\end{array}$ & 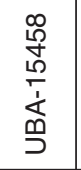 & 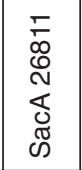 & $\begin{array}{l}\text { ᄋ్ } \\
\text { ర్య } \\
\stackrel{1}{1} \\
0 \\
0\end{array}$ & 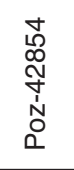 & 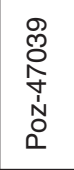 \\
\hline \multicolumn{2}{|c|}{ 这 } & 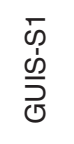 & 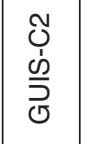 & 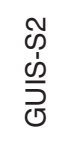 & 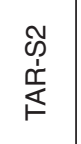 & $\begin{array}{l}\text { on } \\
\dot{n} \\
\tilde{n} \\
0 \\
0 \\
0\end{array}$ & 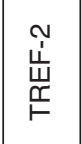 & $\begin{array}{l}\underset{x}{x} \\
\text { }\end{array}$ & गे \\
\hline \multicolumn{2}{|c|}{ 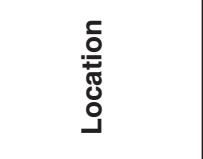 } & 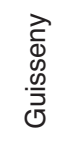 & $\begin{array}{l}\overrightarrow{\widehat{D}} \\
.0 \\
.0 \\
\bar{\Xi}\end{array}$ & 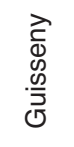 & $\begin{array}{l}\frac{\pi}{0} \\
\frac{0}{0} \\
\frac{0}{\varpi} \\
\text { త్ }\end{array}$ & $\begin{array}{l}\text { 들 } \\
\overline{\bar{E}} \\
\frac{0}{\overline{0}} \\
0\end{array}$ & 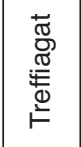 & 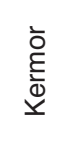 & $\begin{array}{l}\bar{\Phi} \\
\stackrel{\overline{0}}{\overline{0}} \\
\overline{0}\end{array}$ \\
\hline \multicolumn{2}{|c|}{ 希 } & - & $\sim$ & $m$ & $\forall$ & ம & 0 & $\wedge$ & $\infty$ \\
\hline
\end{tabular}

Tab. 3 - New radiocarbon dates and Sea-Level Index Points (SLIPs) and limiting dates. "HL" notation states for "High-Limiting".

Tab. 3 - Nouvelles datations radiocarbones, Sea-Level Index Points (SLIPS) et dates limitantes. HL correspond à « High-limiting ».

gressive flooding of coastal lowlands by the water table, as a primary response to sea-level rise. It generally ends up in a pluri-decametric to 1-m thick brown to black peat bed, often cut at its top by an erosional surface (fig. 2).

\section{Sedimentary palaeoenvironments determination}

The determination of the salinity regime in which basal peats formed is of prime importance. This determination states whether a peat level can be used as a SLIP (this is the case if the peat level formed under saline or brackish influences) or must be only considered as a high-limiting point (if the peat formed in freshwater environments, without any saline influences). In the absence of micro-faunal indicators in our basal deposits, the determination of the salinity regime was achieved using both stable carbon isotope ratios and the observation of macro-plants remains. As local $\delta^{13} \mathrm{C}$ study is still in progress on present-day salt-marsh environments of our study zone, $\delta^{13} \mathrm{C}$ ratios obtained by T.E. Törnqvist et al. (2004), G.P. Wilson et al. (2005), H.H. Lamb et al. (2007), A.C. Kemp et al. (2010) and S. Engelhart et al. (2013) were used as references for discriminating between mud-flats, low-saltmarshes and high-marshes environments. The results of G.P. Wilson et al. (2005) and S. Engelhart et al. (2013) proved especially useful, as the environments they describe are quite similar to those we observed. This led us to consider average $\delta^{13} \mathrm{C}$ values over $16 \%$, between $-17 \%$ ond $-27 \%$ and under $-28 \%$ as limits for saline, brackish to intermediate and strictly freshwater environments, respectively. Nonetheless, the correlation between $\delta^{13} \mathrm{C}$ values and foraminifera assemblages obtained by P. Stephan (2011), led us to slightly reconsider the $-28 \%$ o $\delta^{13} \mathrm{C}$ value, fixed by these studies as the boundary between brackish and freshwater environments. In fact, $\delta^{13} \mathrm{C}$ values as small as $-28,8 \%$ o were obtained by P. Stephan (2011) from deposits identified as high saltmarsh by foraminifera analyses (dominated by Jadammina macrescens and Trochamina inflata species). Nevertheless, taking into account the difficulties to unambiguously discriminate between high-marsh/supratidal environments solely on the basis of $\delta^{13} \mathrm{C}$ values alone (a clearer distinction would require $\mathrm{C} / \mathrm{N}$ measurements as noted by G.P. Wilson et al., 2005 and H.H. Lamb et al., 2007), this indicator will be only used only to confirm brackish conditions and not a RSL proxy. Additional information was retrieved from examination of macro-plant remains if those were easily identifiable. Palynological data were also used when available on the studied deposits.

\section{Palaeo-RSL elevation reconstruction}

Accordingly to O. Van de Plassche (1982), when salt-waterinfluenced basal peats can be clearly identified, they can be 


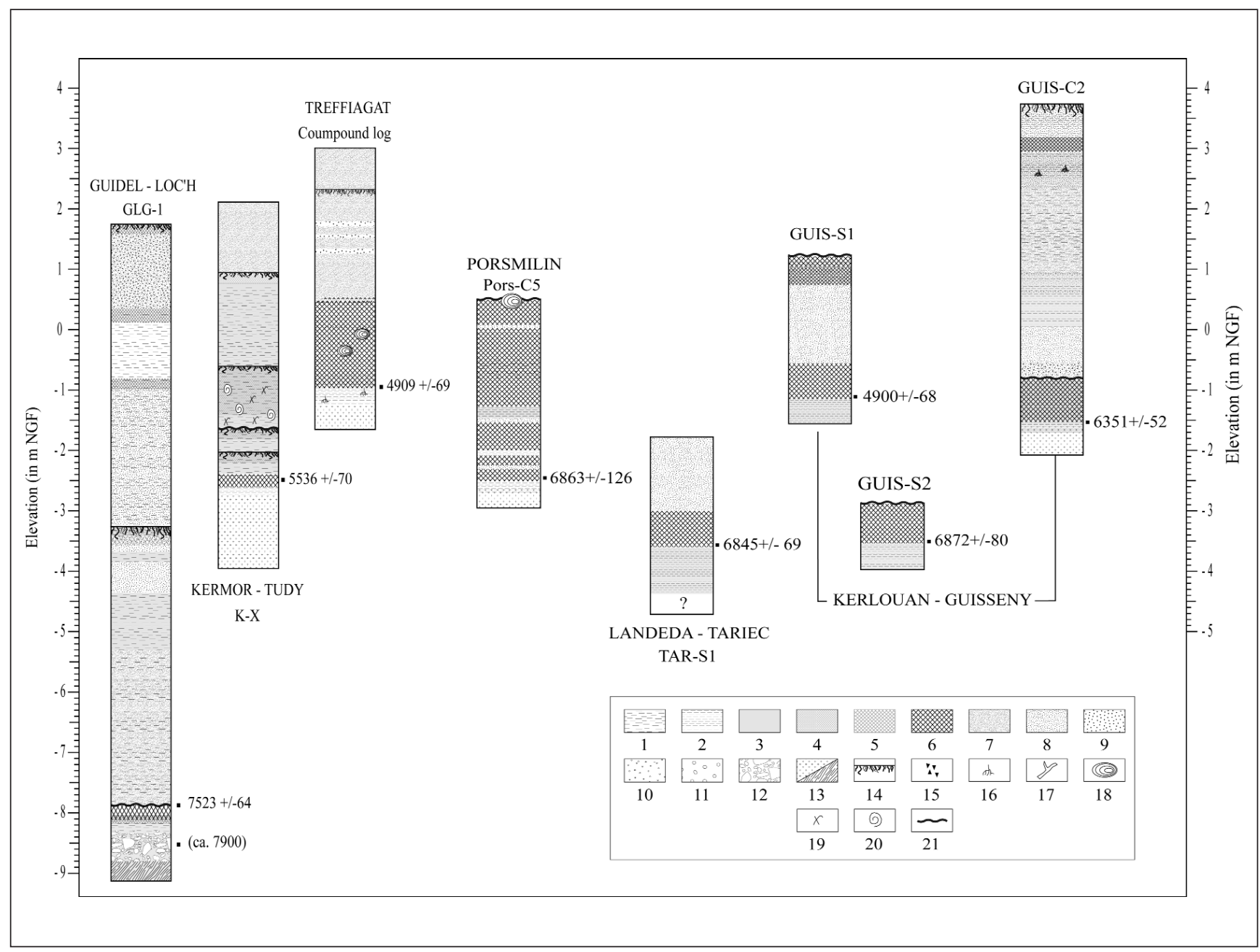

Fig. 2 - Stratigraphic logs of studied cores and drillings. 1: clay; 2: silt; 3: mud; 4: high organic content; 5: humifying level; 6: peat; 7: fine-grained sand; 8: medium-grained sand; 9: coarse-grained sand; 10: gravels; 11: pebbles; 12: fluvial gravels and pebbles; 13: geological substrate/weathered basement (granite/shale); 14: soil; 15: charcoals; 16: roots in living position; 17: wood fragment; 18: wood in living position/tree stem remains; 19: shell fragments; 20: shell in living position; 21: erosion surface.

Fig. 2 - Logs stratigraphiques des carottes et forages étudiés. 1 : argiles ; 2 : limons ; 3 : vase ; 4 : importante fraction organique ; 5 : niveau humifère ; 6 : tourbe ; $7:$ sables fins ; 8 : sables moyens $; 9:$ sables grossiers ; $10:$ graviers ; $11:$ galets ; $12:$ graviers et galets fluviatiles ; 13 : substrat géologique/régolithe (granite/schiste) ; 14 : sol ; 15 : charbons ; 16 : racines en position de vie ; 17 : fragment de bois ; 18 : bois en position de vie/restes de tronc ; 19 : fragments coquillers ; 20 : coquille en position de vie ; 21 : surface d'érosion.

considered as having formed at an altitude between MSL and MHWST. We consider that this indicative range must be adapted on the basis of the $\delta^{13} \mathrm{C}$ data available for our study zone. Indeed, a MSL deposition environment would have led to a very brackish environment characterised by very halophilous plant species, and hence to heavy $\delta^{13} \mathrm{C}$ values. Stable carbon isotope measurements we obtained show that basal peat would rather have formed around the high-marsh / freshwater supratidal limit. Hence, we chose to change the indicative meaning associated to brackish peats and set it between high astronomical tides (HAT) and mean highwater neap tides (MHWNT). Freshwater deposits are considered as high-limiting deposits and form a very maximum for former MHWST levels. Tidal levels were obtained for each site from the data of the nearest tidal-gauge (or tidal reference) station.

\section{Error terms}

The evaluation of the error terms is of particular importance in RSL reconstructions. These error terms must be assessed before any RSL changes can be reliably proposed, and before any comparison between different studies can be attempted (Heyworth and Kidson, 1982; Shennan, 1982, 1986). Possible error sources are the following: (i) inaccurate altitude level of the borehole, (ii) imprecise position of the sampled horizon within the core, (iii) indicative meaning of the sample, (iv) contemporaneous differences of tidal ranges between surveyed site and reference tide-gauge, (v) potential tidal changes over the studied period, (vi) post-depositional compaction, (vii) effects induced by exceptional tides and storm surges, (viii) interferences induced by sedimentary processes (e.g., accumulation rates, peat growth independent from water level, 
Tab. 4 - Data re-assessed from M.-T. Morzadec-Kerfourn (1974). "HL" notation states for "High-Limiting".

Tab. 4 - Données réévaluées depuis M.-T. Morzadec-Kerfourn (1974). La notation HL correspond à « High-limiting».

hiatuses), and (ix) age errors inherent to the radiocarbon dating process and potentially induced by the presence of allochtonous carbon in the sampled deposit. All these errors terms, considered for both our own and re-assessed dates, are detailed below and listed in table 2 .

Both altitudinal and age error terms were quantified in this study. Altitudinal errors consist in the combination of errors associated to the fieldwork (coring, sampling, surveying) and of errors linked to the determination of the indicative meanings and indicative ranges (Shennan, 1986; Van de Plassche, 1986; Gehrels et al., 1996; Brook and Edwards, 2006). Handaugurings are known to be prone to a potential underestimation of the altitude of sampled layers due to the flexion of the rods. Hence, an error of $-2 \mathrm{~cm} / \mathrm{m}$ depth was applied to samples obtained by hand-augurings (Törnqvist et al., 2004). As it was consistently checked in the field, verticality of the percussion and screw-drillings was not taken into account as a possible source of altitudinal error. An error of $\pm 20 \mathrm{~cm}$ was nonetheless assumed for the "twirl" effect potentially induced by the screw-drilling method. A total altitudinal error of $\pm 2 \mathrm{~cm}$ was applied for the GPS-surveys (Suanez et al., 2008). In order to straddle the whole vertical range in which brackish basal peat may have formed, an error term (indicative range) was added to their altitude. Considering the indicative meaning we chose to apply to brackish-influenced basal deposits, this error was fixed to (HAT-MHWNT)/2 and at each site determined from the contemporaneous local tidal range. When tidal levels were obtained by interpolation between tide-gauges stations, an additional error of $\pm 5 \mathrm{~cm}$ was assumed to account for a possible interpolation inaccuracy. We assume the error associated with potential changes in the tidal ranges during the study period to be negligible over the last 7000 years cal. BP, even if no evidence unambiguously supports such an assumption. Modelling work by K. Uheara et al. (2006), though conducted at the scale of northeast Atlantic and thus ignoring a possible influence of changes in local sedimentary environments, predicted that such changes must have been smaller than $0.5 \mathrm{~m}$ over the study period. Age errors were directly obtained from the radiocarbon dating and calibration processes (2- $\sigma$ confidence interval).

\section{New data}

As only basal deposits are addressed in this study, only simplified stratigraphic sequences will be presented (fig. 2). Work on producing fully detailed sequences is still underway and will be presented in a forthcoming paper. Study sites are presented from the north to the south of the study area (fig. 1). The coring sites coordinates are listed in table 1 as well as the tidal setting for each site.

\begin{tabular}{|c|c|c|c|c|c|}
\hline $\overrightarrow{0}$ & 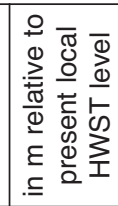 & 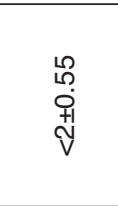 & 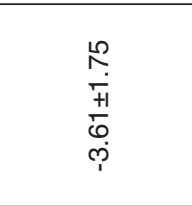 & $\begin{array}{l}\mathscr{L} \\
0 \\
\stackrel{+}{0} \\
0 \\
\infty \\
\dot{亠} \\
\dot{v}\end{array}$ & $\begin{array}{l}\hat{N} \\
+ \\
+1 \\
\stackrel{1}{N} \\
\uparrow\end{array}$ \\
\hline$\stackrel{u}{\underline{a}}$ & & $\overrightarrow{\underline{1}}$ & $\stackrel{\varrho}{\omega}$ & 로 & $\stackrel{\varrho}{\bar{\omega}}$ \\
\hline 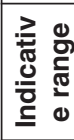 & $\begin{array}{l}\varepsilon \\
. \subseteq\end{array}$ & ' & 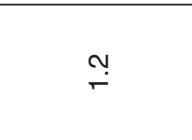 & ' & 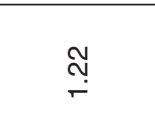 \\
\hline 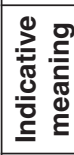 & $\begin{array}{l}\varepsilon \\
. \subseteq\end{array}$ & ' & $\stackrel{+}{\circ}$ & ' & $\begin{array}{c}\hat{m} \\
\stackrel{i}{i}\end{array}$ \\
\hline 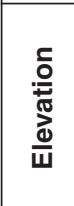 & 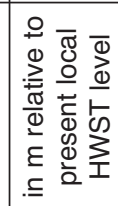 & צ & $\begin{array}{l}\bar{\sigma} \\
\stackrel{+}{+}\end{array}$ & 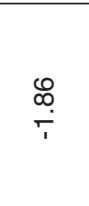 & $\bar{\phi}$ \\
\hline \begin{tabular}{l}
\multicolumn{0}{c}{} \\
$\frac{0}{\bar{\omega}}$ \\
$\frac{\mathrm{d}}{\omega}$ \\
\end{tabular} & $\begin{array}{l}\underline{J} \\
\stackrel{U}{Z} \\
\varepsilon \\
. \subseteq \\
\end{array}$ & 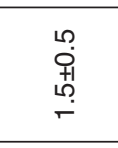 & $\begin{array}{l}\llcorner 0 \\
0 \\
01 \\
11 \\
0 \\
0 \\
\end{array}$ & 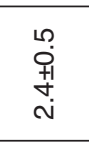 & 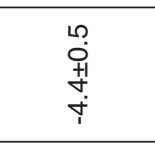 \\
\hline 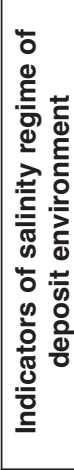 & 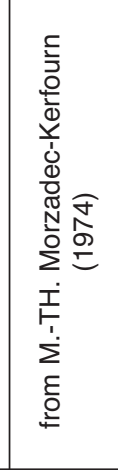 & 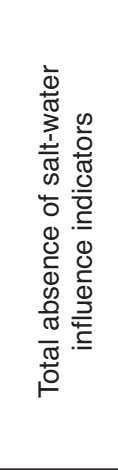 & 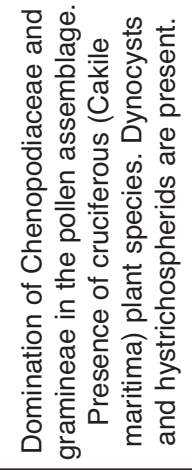 & 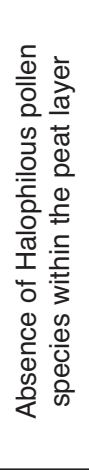 & 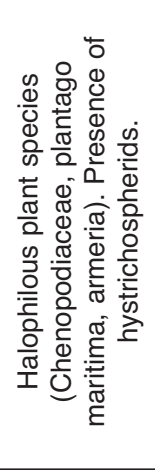 \\
\hline 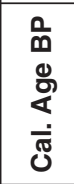 & 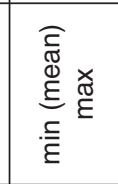 & 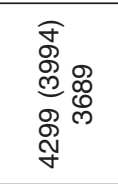 & 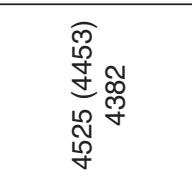 & 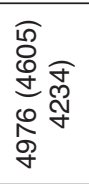 & 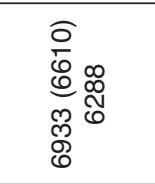 \\
\hline 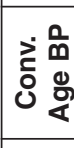 & 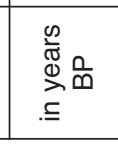 & $\begin{array}{l}\frac{n}{2} \\
\sum_{0}^{+} \\
80 \\
e\end{array}$ & 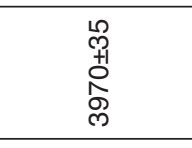 & 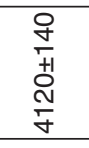 & 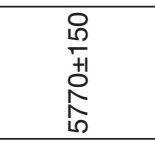 \\
\hline \multicolumn{2}{|c|}{ 윰 } & 㞺公 & $\frac{\dot{L}}{\sigma} \frac{0}{\infty}$ & 㞺六 & 崇 \& \\
\hline \multicolumn{2}{|r|}{ 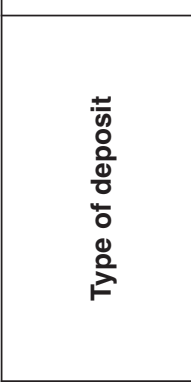 } & 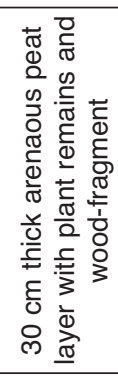 & 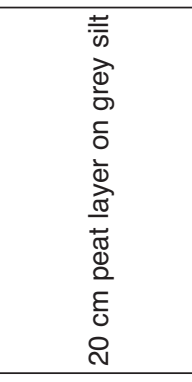 & 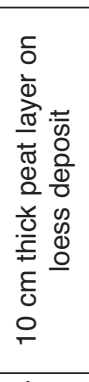 & 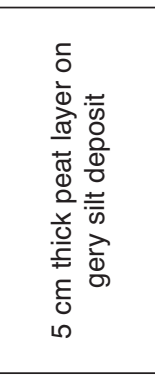 \\
\hline & 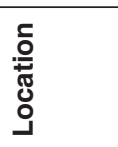 & $\begin{array}{l}\stackrel{\cdot}{\stackrel{D}{N}} \\
\stackrel{\mathbb{N}}{\models} \\
\end{array}$ & 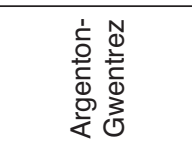 & 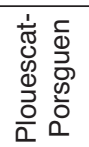 & 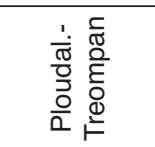 \\
\hline & $\stackrel{\circ}{\check{c}}$ & o & 우 & $F$ & $\simeq$ \\
\hline
\end{tabular}




\section{Kerlouan - Guissény (1. North-Finistère)}

The bay of Tressény is the northernmost site studied in this work. It is a $\mathrm{N} 315^{\circ}$-oriented narrow bay, terminated at its southernmost part by a relatively sheltered salt-mash cove, forming the mouth of the small "Quillimadec" River. The study of Kerlouan-Tressény site was conducted within the framework - and funded by - the Molène Archipelago archaeological research program of the Brittany Region Archaeology Service (Pailler et al., 2011). The present local tidal levels (table 1) were estimated from the two nearest tidal-references stations (Aber-Wrac'h and Brignogan, $10 \mathrm{~km}$ west and east of the site, HAT $=4.74 \mathrm{~m} \mathrm{NGF}, \mathrm{MHWST}=4.06 \mathrm{~m}$ NGF, MHWNT=2.36 m NGF).

\section{Core Guis-C2}

The base of the sedimentary record consists in $0.4 \mathrm{~m}$ of Pleistocene gravel rich clay of probable fluvial origin, progressively topped with $\sim 0.6 \mathrm{~m}$ of a highly-organic stratified peaty-mud, containing very scarce foraminifera and reed fragments. This basal-deposit then evolves into a $0.15 \mathrm{~m}$ layer of black-peat ending in an abrupt erosive contact (-0.8 m NGF). Above this contact rests a $0.6 \mathrm{~m}$ thick sand layer, turning progressively finer from coarse to medium sand. Above, sedimentation alternates between more or less organic silty deposits. Some sand-enriched levels are observed that could be interpreted as either storm deposits for the shell-rich ones or as emplaced by the shifting of river channels. Above $2.95 \mathrm{~m}$ $\mathrm{NGF}$, the sequence becomes highly organic again to the top of the core, the topmost part being composed of the contemporaneous salt-marsh soil (at $3.75 \mathrm{~m} \mathrm{NGF}$ ). The very base of the basal peat-mud layer (-1.52 m NGF) was dated $6351 \pm 52$ cal. BP. Used alone, the $-28.8 \%$ o ${ }^{13} \mathrm{C}$ value does not allow to clearly discriminate between brackish or freshwater supratidal environment but the presence of reeds leaves remains and foraminifera attests for brackish influences. Former MHWST on the site ca. $6351 \pm 52$ cal. BP can hence be positioned at $-5.06 \pm 1.26 \mathrm{~m}$ below contemporaneous MHWST level (Index no. 2).

\section{Cores Guis-S1 and S2}

Two hand-augurings were made at the bottom of the Vougot beach situated at the mouth of Tressény cove. The first core (Guis-S1) recovered $0.6 \mathrm{~m}$ of a brown reed peat resting on the Pleistocene loess layer. Overlying this peat deposit is $\sim 1.6 \mathrm{~m}$ of white sand, progressively gaining in organic content towards its top, till it becomes a true sandy-peat layer at $\sim 1.05 \mathrm{~m}$ NGF. The topmost $10 \mathrm{~cm}$ of the core correspond to the darkmassive brown peat layer today outcropping at the bottom of the beach. Base of the base peat layer $(-1.15 \mathrm{~m} \mathrm{NGF})$ was dated to $4900 \pm 68 \mathrm{cal}$. B.P (UBA 15461). Reed fragments reveal a brackish deposit environment, confirmed by the ${ }^{13} \mathrm{C}$ value yielding $-28 \%$. This deposit was considered to have formed between HAT and MHWNT and permitted to reconstruct a RSL position of $-4.69 \pm 1.31 \mathrm{~m}$ below contemporaneous ones for the $4900 \pm 68 \mathrm{cal}$. BP period (Index no. 1). The second core (Guis-S2) permitted to retrieve $0.65 \mathrm{~m}$ of brown peat before reaching the underlying loess formation. Base of the peat was dated to $6872 \pm 80 \mathrm{cal}$. BP (UBA 15460) at $3.52 \mathrm{~m}$ NGF. Its brackish character is attested by a heavy $\delta^{13} \mathrm{C}$ value of $-23.4 \%$. Hence, the palaeo-RSL at $6872 \pm 80$ cal. BP can be positioned at $-7.06 \pm 1.27 \mathrm{~m}$ under the present MHWST level (Index no. 3).

\section{Landéda - Tariec (2. North-West Finistère)}

An auguring was drilled on the foreshore of the Sainte Marguerite dunes, a $\mathrm{N} 315^{\circ}$-exposed site, located between the mouths of two large rivers (Aber-Benoît and Aber-Wrac'h). Local present tidal levels (table 1) were directly obtained from the Aber-Benoît tidal-reference situated $\sim 3 \mathrm{~km}$ from

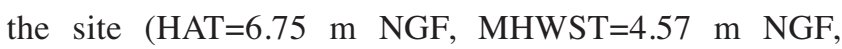
MHWNT=2.13 m NGF). An approximately 0.6-m thick peat deposit was reached at $-3 \mathrm{~m}$ NGF, under $\sim 1 \mathrm{~m}$ of sand. This basal peat lies over a Pleistocene loessy silt level of unknown thickness. It consists of a highly fibrous peat, principally composed of embedded reed-leaves fragments, suggesting a brackish swamp sedimentation environment. Base of the peat layer yielded an age of $6845 \pm 69 \mathrm{cal}$. BP at $3.6 \mathrm{~m} \mathrm{NGF}$. This date is thus contemporaneous with that of the peat layer of the Curnic beach. As already revealed by the reeds remains embedded in the peat, the brackish conditions and a probable high-marsh environment of deposition are confirmed by a $\delta^{13} \mathrm{C}$ value of $-26.9 \%$. Palaeo-RSL position on the site $\sim 6845 \mathrm{cal}$. BP was $-6.95 \pm 1.27 \mathrm{~m}$ under present MHWST (Index no. 4).

\section{Porsmilin (3. Western end of the Finistère peninsula)}

Porsmilin is a cove situated in the Bertheaume Bay. The site comprises a small sandy beach limited landward by a small dune barrier which somewhat isolates a presently filled marsh. On the foreshore of the beach a large step of peat crops out, covered with fallen tree stems. The exceptionally good state of conservation of the deposit in such a situation ( $\mathrm{S}$ to $\mathrm{SW}$-oriented beach, highly exposed to storm swells), was an incentive to retain Porsmilin as a study site in the framework of the COCORISCO project. Five pistoncores were carried out from the foreshore to the bottom of the back-barrier but only the lowermost core (Pors-C5) reached Holocene basal deposits. Local present tidal levels (table 1) were determined according to the Trez-Hir tidal reference situated at $\sim 2 \mathrm{~km}$ west of the site (HAT $=3.99 \mathrm{~m}$ NGF, MHWST=3.17 m NGF, MHWNT=1.67 m NGF). Core PorsC5 was made from a peat-step surface cropping out at the bottom of the beach. The weathered basement was reached at an approximate depth of $3.25 \mathrm{~m}$ below the surface. On top lies $25 \mathrm{~cm}$ of Pleistocene sandy silt, which becomes progressively organic in its upper part before turning in a $0.15 \mathrm{~m}$ thick black peat deposit at around $-3.5 \mathrm{~m}$ NGF. A complex high frequency layering of organic-mud and peat patterns makes up the rest of the sequence. The base of the basal peat deposit was dated on organic content to $6863 \pm 127$ 
cal. BP at $-2.45 \mathrm{~m}$ NGF. The high $\delta^{13} \mathrm{C}$ value (-21\%o) seems to clearly attest for a brackish-influenced intertidal environment (e.g., lagoonal marsh). Poacea and Cyperacea pollen spores were found to dominate the plant palynological assemblages (A. Fernane, pers. comm.). Whilst species were not differentiated, this could correspond to brackish adapted plant species such as Spartina altinerflora, Phragmitus australis and Juncus roemarianus, respectively. If it appears that this deposit may have formed in brackish conditions, we consider that we lack sufficiently reliable indicators to use it as a SLIP. It was therefore taken as a high-limiting deposit, constraining the former MHWST level to lay at a maximum of $5.62 \mathrm{~m}$ below present one around $6863 \pm 127 \mathrm{cal}$. BP.

\section{Treffiagat (4. South Finistère)}

Treffiagat is a flat south-oriented site situated in the south of our study zone. A large dune-barrier isolates a back-barrier swamp today still awash with water. On the foreshore just in front of the dune an important peat body is cropping out, eroded seaward by a micro-cliff. Two piston-cores were taken near the swamp in the back-barrier zone, respectively at $2.2 \mathrm{~m} \mathrm{NGF}$ and $1.75 \mathrm{~m} \mathrm{NGF}$. Local present tidal levels (table 1) were determined according to the tidal reference of Le Guilvinec harbour, situated directly to the west of the site $(\mathrm{HAT}=4.20 \mathrm{~m} \mathrm{NGF}, \mathrm{MHWST}=3.16 \mathrm{~m} \mathrm{NGF}, \mathrm{MHWNT}=$ $1.56 \mathrm{~m} \mathrm{NGF}$ ). The observed sequence begins at $-1.25 \mathrm{~m}$ NGF with $\sim 0.3$ m of a probably Pleistocene silty-mud complex overlaying the weathered basement. This deposit contains many traces of oxidation and undated roots remains, attesting of its surface exposure. Above, lies a 30-cm thick organic silty-peat layer, progressively turning into a wooden black peat above $c a$. $-0.7 \mathrm{~m}$ NGF. This peat layer is capped by $\sim 1.80$ m of sand-barrier medium to coarse sand. A date was obtained on organic contents at the transition between the Pleis-

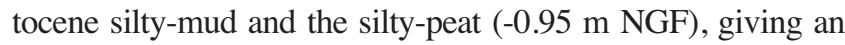
age of $4909 \pm 69 \mathrm{cal}$. BP. No arguments exist to date in favour of a brackish or freshwater deposit environment. This deposit was hence considered as high-limiting, and led to assess that former mean MHWST level was at least $-3.61 \mathrm{~m}$ below contemporaneous MHWST ca. 4900 cal. BP (Index no. 6).

\section{Kermor - Tudy (5. South Finistère)}

The site of Kermor/Tudy is situated in the Bénodet cove. The site is composed of a large dune barrier oriented $\mathrm{N} 135^{\circ}$ that isolates a back-barrier lagoon nowadays polderized. Several drillings were taken in the polder in the back-barrier zone. Only one drilling taken at the eastern end of the site, near to the barrier root, permitted to reach basal peat deposits. Local contemporaneous tidal levels (table 1) were determined accordingly to the tidal reference for the harbour of Loctudy situated directly northwest of the site (HAT=3.09 m NGF, MHWST=2.45 m NGF, MHWNT=1.35 m NGF). Core K-X reached the weathered geological substrate at a depth of $4 \mathrm{~m}$, the top of the core being situated at $1.3 \mathrm{~m} \mathrm{NGF}$. The base of the sequence is composed by a $0.1-\mathrm{m}$ thick sandy silt layer, progressively evolving into a black peat until $\mathrm{ca}$. $-2.6 \mathrm{~m}$ NGF.
Superimposed on this peat level is $0.8 \mathrm{~m}$ of very organic stratified silt horizons. On top of a sharp sedimentary hiatus appears a Hydrobia ulvae-dominated marine mud layer. This layer becomes more and more organic to the top (grey to brown mud, with less shell fragments, implying a probable salt-marsh facies) until ca. $-1 \mathrm{~m} \mathrm{NGF}$. The uppermost part of the core is composed of $1.3 \mathrm{~m}$ of brown to green clay, on which rests a dune sand level. The basal peat was dated on organic content to $5536 \pm 70 \mathrm{cal}$. BP. at $-2.49 \pm 0.22 \mathrm{~m} \mathrm{NGF}, \sim 10 \mathrm{~cm}$ above the contact between the sandy silt and the peat. No clear argument could help us to determine the original deposit environment. Hence, this sample was considered as a high-limiting point. It constrains the former MHWST level to a lay at a maximum of $-4.94 \pm 0.22 \mathrm{~m}$ under present one (Index no. 7). Due to the elevation uncertainties induced by the sampling method, it cannot be fully attested that this deposit is a "pure" compaction-free basal peat. It must so be kept in mind that it could have undergone an unknown compaction-induced lowering.

\section{Guidel (6. South Finistère)}

Guidel-Loc' $h$ is the southernmost site of this study. It consists in a south $225^{\circ}$-oriented ria, polderized since the 19th c. Two screw drillings were completed along a SW/NE transect across the Guidel-Loc' $h$ pond: GLG-1 was drilled in the middle of the pond, while GLG-2 was drilled about $500 \mathrm{~m}$ seaward. Only GLG-1 reached a basal peat deposit. Local contemporaneous tidal levels were determined according to the tidal reference of Le Pouldu situated at $\sim 2 \mathrm{~km}$ north of the site (HAT=2.78 $\mathrm{m} \mathrm{NGF,} \mathrm{MHWST=2.23} \mathrm{m} \mathrm{NGF,}$ MHWNT=1.18 m NGF). GLG-1 is an 11-m deep drilling, reaching the micaschist, weathered basement at $-8.3 \mathrm{~m}$ NGF. The base of the sequence consists of ca. 0.2 meter of lacustrine clay encroaching the weathered, micaschist basement. It may represent a lacustrine environment that was emplaced as a result of the hampered drainage in the RSL rise context or a Pleistocene floodplain deposit. The centre of this layer was dated to $c a .7900$ cal. BP in GLG-2 drilling, but we also consider probable that this datation could have been rejuvenated by roots penetration. The clay evolves upwards into a $20 \mathrm{~cm}$ silty peat layer, overlaid in unconformity by $2.5 \mathrm{~m}$ of silty sand. The sequence continues with a succession of $7 \mathrm{~m}$ of a sand and muddy-silty layers interrupted by several organic-rich salt-marsh soils. The roof of the sequence is composed of $1 \mathrm{~m}$ of sandy marine deposits. The basal-peat and the underlying silt deposit was dated to $7523 \pm 64$ cal. BP on organic fragments embedded in the peat matrix at $-7.87 \pm 0.22 \mathrm{~m}$ NGF. In the absence of microbiological or geochemical indicators, this layer could only be considered as a high-limiting deposit. It led to assess a former maximum MHWST level of $-10.1 \pm 0.22 \mathrm{~m}$ below the present one (Index no. 8). As it cannot be ruled out that the underlying clay deposit is totally compaction-free and because the peat layer was not sampled at its very base, a potential shortcoming exists in the representativeness of this deposit as a basal-deposit. Thus, again, it cannot be considered as a fully reliable upper-constraint of the RSL and must be only considered as indicative. 


\section{Previous studies re-assessment}

In order to allow comparisons between our results and previously published ones, former RSL results had to be reassessed. Such a re-assessment requested older data to be re-processed through the same method we used.

\section{Original methodology}

M.-T. Morzadec-Kerfourn (1974) constructed a Holocene RSL curve for northwestern Brittany based on 15 radiocarbon dates. Results were presented in an age/altitude diagram. Though the question of the importance of altitude and age error terms was originally addressed in the text, these error terms were taken into account neither in the data analysis nor in the curve construction. An estimation of possible errors must therefore be re-addressed. The deposits were observed and sampled either on outcrops or by the use of a hand-drilling instrument. Altitudes were presented in $\mathrm{m} \mathrm{NGF,} \mathrm{even} \mathrm{if} \mathrm{no} \mathrm{de-}$ tails were given on the levelling method used. The deposit environments of the layers were originally determined by M.T. Morzadec-Kerfourn using palynological assemblages and absence/presence of dynocysts. The deposits were hence described as either fresh or brackish and related to a relative a sea-level position. Past RSL positions were determined and linked to actual HWST level on the study sites. Error terms on the indicative ranges of brackish peat deposits are lacking. In addition, archaeological megaliths were used in order to refine past HWST maxima. Radiocarbon datings were performed on wood fragments and bulk deposits and presented as conventional carbon ages.

\section{Re-assessments}

In the absence of information concerning the levelling methods used by M.-T. Morzadec-Kerfourn (1974) and the potential uncertainty of those used in the 1970s, a conservative $\pm 0.5 \mathrm{~m}$ vertical error term was tied to the elevation of sampled deposits. Indicative meanings of M.-T. MorzadecKerfourn were re-assessed following the approach used in the present study. As error terms on the indicative ranges of brackish peat deposits were found lacking in the original paper, those were fixed, as above, as equal to (HAT-HWNT)/2, as can be measured on present-day tidal ranges on the sites. Above cited error terms are listed in table 2. All dates were recalibrated with respect to modern standards. After re-calibration, the dates close to the boundaries of the study period show a spectacular mean shift of 300 years, even reaching 840 years for GIF-766 (index-point number 12, 6610 \pm 323 cal. BP). All the dates retained from the work of M.-T.

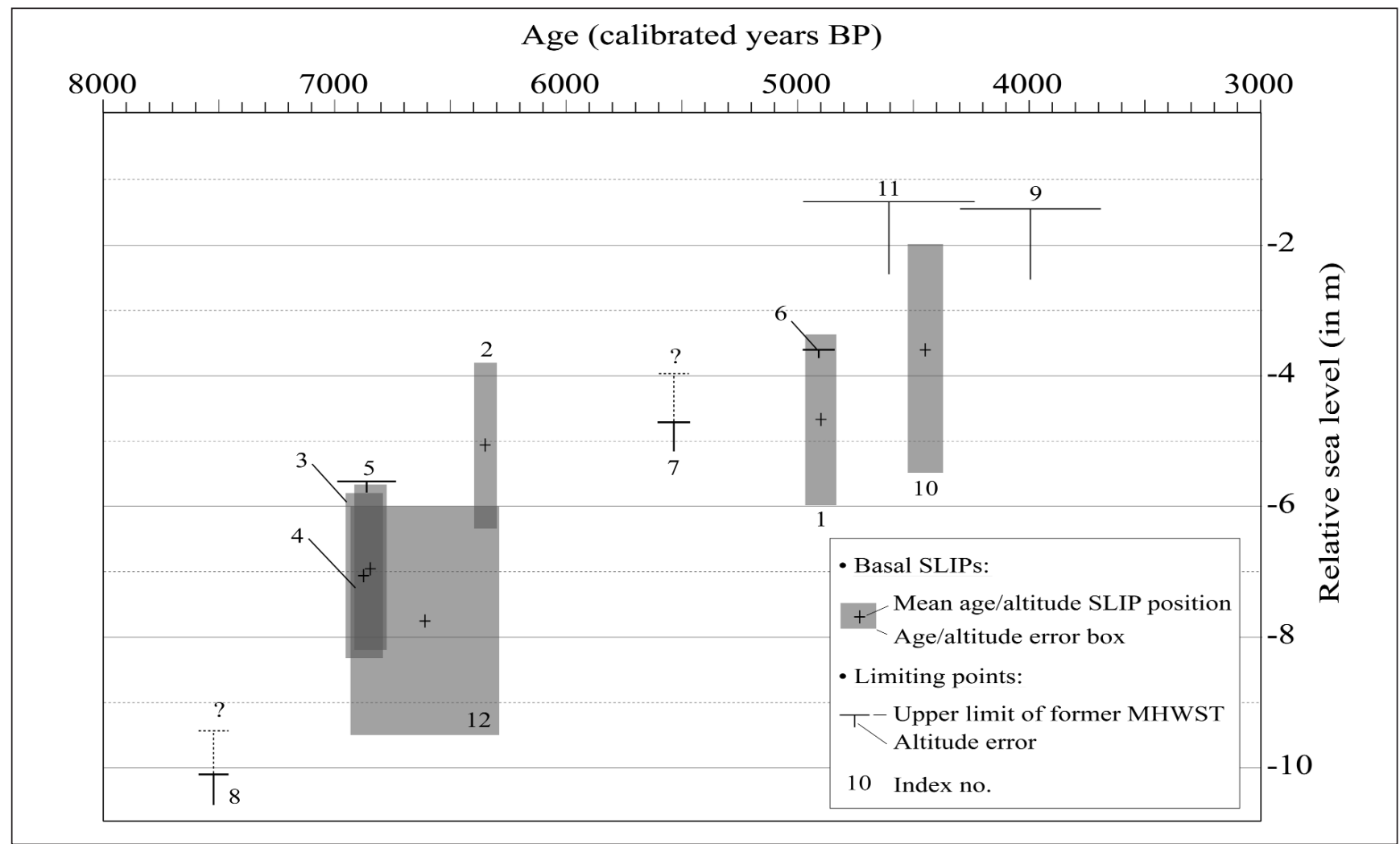

Fig. 3 - Former Holocene RSL positions derived from basal peat deposits dated ca. $7600-4000$ cal. BP in the Finistère region. A detailed legend is included in the figure. Numbers correspond to table 3 and table 4 . Dotted lines indicates points for which potential compaction cannot be ruled out.

Fig. 3 - Positions passées du niveau marin relatif holocène dans le Finistère obtenues à partir des tourbes de base pour la période entre environ 7600 et 4000 cal. BP. Légende incluse dans la figure. La numérotation correspond au tableau 3 et au tableau 4. Les pointillées indiquent les points pour lesquels une potentielle compaction ne peut être exclue. 
Morzadec-Kerfourn (1974) are presented in table 4, accompanied by their original summarised stratigraphic, palynological and micro-faunal data.

\section{Results and discussion}

\section{Basal peat based long-term RSL reconstruction}

Four new basal SLIPs, together with two others re-assessed from previously published work (Morzadec-Kerfourn, 1974) and six limiting dates are used to reconstruct long-term (millennial) trends of western Brittany RSL history from $c a .7600$ and $c a .4000$ cal. BP. Total RSL rise reaches $c a .10 \pm 0.2 \mathrm{~m}$ since $c a .7500 \mathrm{cal}$. BP (fig. 3). The RSL rise seems to slow down $c a .7000 \mathrm{cal}$. BP, to an average value of ca. $0.92 \mathrm{~mm} / \mathrm{a}$ until ca. $4500 \mathrm{cal}$. BP. A gap in the data exists between $\mathrm{ca} .6300$ and $5000 \mathrm{cal}$. BP, period from which only one basal peat could be retrieved within the sequences we worked on: Limiting date no. 7 constrains the rising tendency and indicates a RSL being $-4.7 \mathrm{~m}$ below present-day HWST around 5500 cal. BP but it cannot be fully attested that this point has not undergone some lowering due to compaction. No SLIPs were obtained from basal-peat data after ca. $4500 \mathrm{BP}$ (fig. 3).

\section{Comparison with RSL data based on the study of foraminifera}

P. Stephan (2011) published a Holocene RSL curve for the Bay of Brest, based on 15 SLIPs retrieved from three cores obtained in saltmarshes. Indicative meanings were originally determined by a transfer function, constructed from two present-day salt-mashes of the Bay of Brest. Log and reconstructed palaeo RSL are presented in fig. 4. Dates were recalibrated with respect to our standard to allow comparisons. As underlined by P. Stephan (2011), all dates he used were obtained on bulk deposits and hence may have suffered dating problems.

Stephan's SLIPs plot in relatively good accordance with our basal SLIPs (fig. 5). Vertical discrepancy between our data and P. Stephan's one can be explained by the fact that 13 of the 15 dates published by this author were obtained from intercalated deposits particularly prone to compaction, while it could not have been the case for the basal peats we worked on. On the meantime, two of the 15 SLIPs published by P. Stephan (2011) are also basal deposits and it can be observed that these also plot quite low regarding our data. The $c a .2800$ BP point was obtained from the base of a basal mud deposit full of fragmented shells. We believe that this point may have been reworked and deposited in a highly-

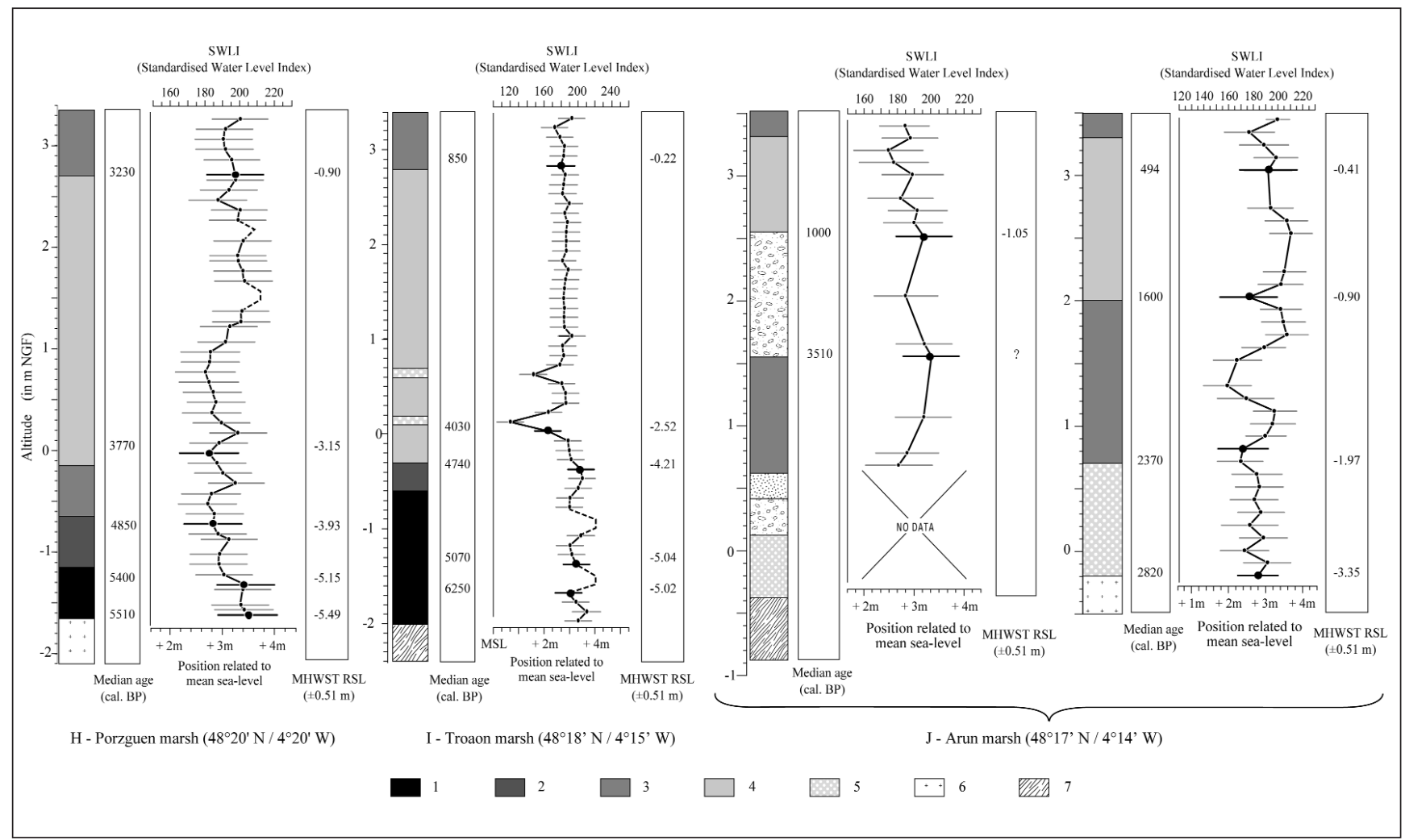

Fig. 4 - Sedimentary sequences studied in the Bay of Brest by P. Stephan (2011) and associated RSL positions. Modified from P. Stephan (2011). Data as originally published. 1: peat; 2: silty-peat 3: organic mud; 4: marine mud; 5: shelly mud; 6: bed-rock (granite); 7 : bed-rock (shale)

Fig. 4 - Séquences sédimentaires étudiées par P. Stephan (2011) en Rade de Brest et positions associées du niveau marin relatifs. Modifié de P. Stephan (2011). Données telles qu'originalement publiées. 1: tourbe ;2: tourbe argileuse ; 3: vase organique ; 4: vase marine ; 5: vase coquillère ; 6 : substrat granitique ; 7: substrat schisteux. 


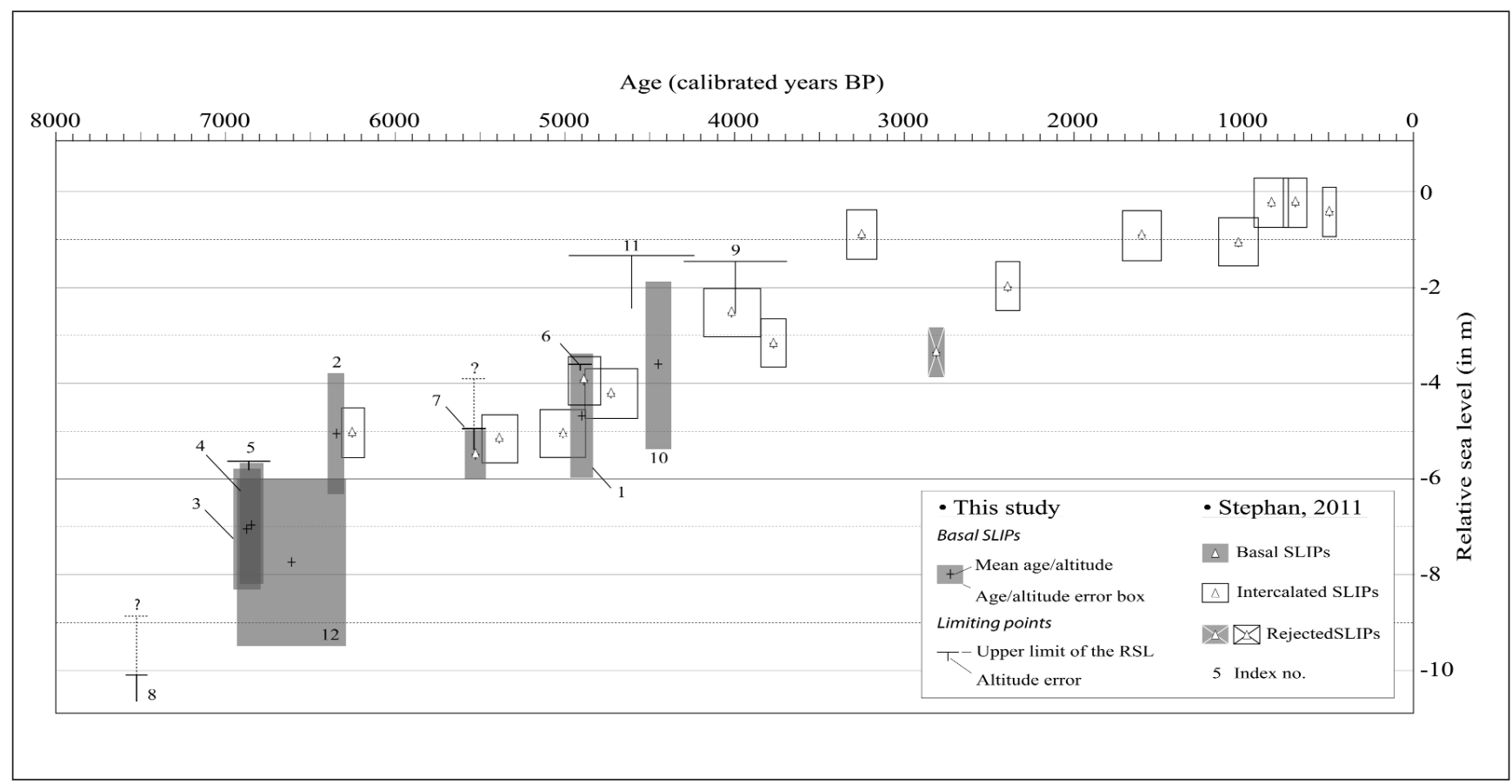

Fig. 5 - Comparison of long-term RSL reconstruction based on basal peats (this study) and data obtained by P. Stephan (2011) from foraminifera analyses. Numbers correspond to table 3 and table 4. Dotted lines indicated that some potential compaction cannot be ruled out.

Fig. 5 - Comparaison entre les données de niveau marin relatif obtenues dans cette étude à partir des tourbes de base et celles obtenues par P. Stephan (2011) à partir de l'étude des foraminifères. La numérotation correspond au tableau 3 et au tableau 4 . Les pointillées indiquent les points pour lesquels une potentielle compaction ne peut être exclue.

morphogenic period, probably after an erosional event that artificially created an accommodation space and induced a lowering of the subsequent sedimentary infill. If this is the case, it casts doubts on its usefulness for RSL reconstruction purpose. We therefore considered this point as unreliable and chose to reject it for RSL reconstruction purpose. Indeed, $c a$. $3000 \mathrm{BP}$ period is widely recognised in northwestern Europe (Lamb, 1977; Long and Hughes, 1995; Moura et al., 2007) as a period of highly increased storminess during which large perturbations on the sedimentary sequences may have occurred. The $5500 \mathrm{cal}$. BP point is more doubtful. As noted by P. Stephan (2011), the foraminifera assemblage obtained for this point had no modern analogues and thus reliability of the RSL position produce by the foraminifera transfer function may have been biased. Moreover, it was dated on bulk peat material, it cannot be ruled out this date was not rejuvenated by roots penetration.

Large uncertainties remain on RSL changes during the $c a$. 6300-5000 cal. BP period. Indeed, considering the doubtful basal SLIP presented above, RSL evolution during the former period is only constrained by three SLIPs and one limiting date, which contribute to give to the RSL envelope a somewhat stabilising to character that cannot be at all ascertained, due to the lowering effect compaction surely had on these points. Further work is clearly needed in order to precise the RSL behaviour within this time-period.

In spite of the above mentioned uncertainties and when the maximal extents of the SLIPs error boxes and limiting dates are taken into account, simplified RSL sub-trends can reliably be drawn between $c a$. 7500 and 7000 cal. BP and between $\mathrm{ca} .7000$ and $3000 \mathrm{cal}$. BP, corresponding to mean RSL rise rates of $c a .8 \mathrm{~mm} / \mathrm{a}$ and $1.4 \mathrm{~mm} / \mathrm{a}$, respectively (fig. 5). After ca. 3400 cal. BP, P. Stephan data give an average rising rate of $c a .0 .31 \mathrm{~mm} / \mathrm{a}$. We stress the fact that these average "sub-rates" must only be considered as indicative values, as they do not take quantitatively into account the errors tied to both the basal SLIPs and the high-limiting points and because of the uncertainties around the periods of RSL rise rates changes. RSL data still lack definition $c a$. 6000 cal. BP and ca. 3000 cal. BP to undoubtedly state on the RSL behaviour around these periods. Indeed, it cannot be ruled out that "stair-steps" of either stabilising or veryslowly rising RSL did not take place in between the more clearly defined transgressive periods. We speculate that barrier (and hence back-barrier) environments may have been particularly impacted during those decreasing RSL rising rates periods, surely bearing consequences on the RSL signal recorded as it was noted by A.C. Massey et al. (2008). Particularly, we speculate that compaction processes surely had major impacts on back-barriers lagoonal deposits during barriers landward shifts.

\section{Conclusions}

New data were obtained on Holocene RSL for the western Brittany region and allowed RSL history to be recon- 
structed on a longer period than was previously possible in the region. These new data are in good agreement with the data published in previous studies, after the latter have been re-assessed. Our work gives a new and more precise overall vision on RSL changes in western-Brittany during the Holocene.

Basal peat deposits obtained from several sites around the Finistère peninsula show long-term millennial trends of RSL during the study period. RSL was situated around $-10 \mathrm{~m}$ under present-day level $c a$. $7500 \mathrm{cal}$. BP, between -7 and $-5 \mathrm{~m} \mathrm{ca}$. $7000 \mathrm{cal}$. BP, and around $-1 \mathrm{~m} \mathrm{ca} .3200 \mathrm{cal}$. BP. The study of basal peat only allowed a long-term RSL reconstruction, but this reconstruction nevertheless reliably shows that the rate of the sea-level underwent a dramatic decrease ca. $7000 \mathrm{cal}$. BP and a further, if more minor, surely somewhere between 4000 and $3000 \mathrm{cal}$. BP. The comparison with foraminifera-based RSL data obtained in the region shows the good accordance between the datasets. Elevation discrepancies between both datasets can surely be partly attributed to compaction having lowered the elevation of non-basal Holocene deposits. Hence, it allows to gain in point density and to reach a better resolution for RSL reconstruction, as foraminifera-based RSL data available for the region obviously lacked basal compaction free-deposits while our data take advantage of the better-constrained elevation of the foraminifera-based SLIPs. It tends to confirm that RSL rise occurred at progressively decreasing rates before $c a .7000 \mathrm{cal}$. BP, between $c a .7000$ and $c a .3000$ cal. BP, and after ca. 4000-3000 BP. Doubts remain on the turning points of RSL rise changes because of pluri-centennial gaps existing between the dates around these periods. Dating-related problems are also suspected for some of the index-points defining those changes. It can be suspected that periods of diminishing rate in RSL rise each time provoked deep modifications in the functioning of the back-barrier sedimentary systems from where most of the data were retrieved.

Further work is in progress to incorporate additional data obtained in several sites along the Brittany. When completed, this work will allow to better constrain the RSL history of western Brittany and will be of great importance to better understand the morphosedimentary dynamics that took place during the Holocene in reaction to the different changes in the RSL rise rates.

\section{Acknowledgements}

This work is a contribution to the ANR COCORISCO (French National Research Agency program for coastal risks assessment and management, ANR 2010-CEPL-00101, Pôle-mer Bretagne). ANR COCORISCO, Domaines Océaniques laboratory (UMR CNRS 6538), GEOMER laboratory (UMR CNRS 6554) funded equipment, fieldwork, sample analysis and datings, together with PHILTRE and ARTEMIS programs. Town councils and the Conservatoire $d u$ Littoral provided full access to the study sites. Special thanks to Luigi Ardito (BRGM) for his drilling expertise. Finally, we are extremely grateful to the two anonymous reviewers whose constructive comments significantly helped to improve this paper.

\section{References}

Baeteman C., Beets D.J., Strydonck M.V. (1999) - Tidal crevasse splays as the cause of rapid changes in the rate of aggradation in the Holocene tidal deposits of the Belgian Coastal Plain. Quaternary International 56, 3-13.

Baeteman C., Waller M., Kiden P. (2011) - Reconstructing middle to late Holocene sea-level change: A methodological review with particular reference to 'A new Holocene sea-level curve for the southern North Sea' presented by K.-E. Behre. Boreas 40, 557-572.

Beets D.J., Van Der Spek A.J.F. (2000) - The Holocene evolution of the barrier and the back-barrier basins of Belgium and the Netherlands as a function of late Weichselian morphology, relative sea-level rise and sediment supply. Netherlands Journal of Geoscience 79-1, 3-16.

Behre K.E. (2007) - A new Holocene sea-level curve for the southern North Sea. Boreas 36, 82-102.

Berendsen H.J.A., Makaske B., Van de Plassche O., Van Ree M.H.M., Das S., Van Dongen M., Ploumen S., Schoenmakers W. (2007) - New groundwater-level rise data from the RhineMeuse delta - implications for the reconstruction of Holocene relative mean sea-level rise and differential land-level movements. Netherlands Journal of Geoscience 86-4, 333-354.

Bonnet S., Guillocheau F., Brun J.P., Van Den Driessche J. (2000) - Large-scale relief development related to Quaternary tectonic uplift of a Proterozoic-Paleozoic basement: the Armorican Massif, NW France. Journal of Geophysical Research 105, B8, 19273.

Bradley S., Milne G.A., Shennan I., Edwards R. (2011) - An improved Glacial Isostatic Adjustment model for the British Isles. Journal of Quaternary Science 26, 5, 541-552.

Brain M.J., Long A.J., Petley D.N., Horton B.P., Allison R.J. (2011) - Compression behaviour of minerogenic low energy intertidal sediments. Sedimentary Geology. 233, 28-41.

Brooks A., Edwards R. ( 2006) - The Development of a Sea-Level Database for Ireland, Irish Journal of Earth Sciences 24, 13-27.

Bungenstock F., Schäfer A. (2009) - The Holocene relative sealevel curve for the tidal basin of the barrier island Langeoog, German Bight, Southern North Sea. Global and Planetary Change $66,34-51$

Bungenstock F., Weerts H.J.T. (2010) - The high-resolution Holocene sea-level curve for Northwest Germany: global signals, local effects or data-artefacts? International Journal of Earth Sciences (Geologische Rundschau) 99, 1687-1706.

Clavé B., Massé L., Carbonel P., Tastet J.-P. (2001) - Holocene coastal changes and infilling of the La Perroche marsh (French Atlantic coast). Oceanologica Acta 24, 4, 377-389.

Chmura G.L., Aharon P. (1995) - Stable Carbon Isotope Signatures of Sedimentary Carbon in Coastal Wetlands as Indicators of Salinity Regime. Journal of Chemical Research 11-1, 124-135.

Delibrias G., Guillier M.T. (1971) - The sea level on the Atlantic coast and the Channelfor the last 10,000 years by the ${ }^{14} \mathrm{C}$ method. Quaternaria 14, 131-135.

Denys L., Baeteman C. (1995) - Holocene evolution of relative sea level and local mean high water spring tides in Belgium - a first assessment. Marine Geology 124, 1-19. 
Edwards R.J. (2006) - Mid- to late-Holocene relative sea-level change in southwest Britain and the influence of sediment compaction. The Holocene 16-4, 575-587.

Edwards R.J. (2007) - Sea levels: resolution and uncertainty. Progress in Physical Geography 31, 621.

Edwards R.J., Horton B. (2007) - Developing detailed records of relative sea-level change using a foraminiferal transfer function: an example from North-Norfolk, UK. Philosophical Transactions of the Royal Society A 364, 973-991.

Engelhart S., Horton B.P., Vane C.H., Nelson A.R., Witter R.C., Brody S.R, Hawkes A.D. (2013) - Modern foraminifera, $\delta^{13} \mathrm{C}$, and bulk geochemistry of central Oregon tidal marshes and their application in paleoseismology. Palaeogeography, Palaeoclimatology, Palaeoecology 377, 13-2.

Evans C.D.R. (1990) - United Kingdom Offshore Regional Report: the Geology of the Western English Channel and its Western Approaches. British Geological Survey, NERC, HMSO, London, $94 \mathrm{p}$.

Fairbridge R.W. (1961) - Eustatic changes in sea level. In Ahrens L.H, Press F., Rankama K., Runcom S.K. (Eds.): Physics and Chemistry of the Earth 4, 99-185.

Fouache E. (2006) - 10000 ans d'évolution des paysages en Adriatique et en Méditerranée orientale (géomorphologie, paléoenvironnements, histoire). Travaux de la Maison de l'Orient et de la Méditerranée, 45, Lyon, 232 p.

Gandouin E., Van Vliet-Lanoë B., Franquet E., Andrieu-Ponel V., Keen D.H., Ponel P., Meurisse M., Brulhet J., Brocandel M. (2007) - Analyse en haute résolution de la transgression holocène dans un secteur subsident du littoral français: le bassinmarais de St Omer (Pas de Calais, France). Géologie de la France, 2007, 1, 11-32.

Gehrels W.R. (1999) - Middle and late Holocene sea-level changes in eastern Maine reconstructed from foraminiferal saltmarsh stratigraphy and AMS ${ }^{14} \mathrm{C}$ dates on basal peats. Journal of Quaternary Research 52, 350-359.

Gehrels W.R., Belknap D.F. (1993) - Neotectonic history of eastern Maine evaluated from historic sea-level data and ${ }^{14} \mathrm{C}$ dates on salt-marsh peats. Geology 21, 615-618.

Gehrels W.R., Belknap D.F., Pearce B.R., Gong B. (1995) Modeling the contribution of M2 tidal amplification to the Holocene rise of mean high water in the Gulf of Maine and the Bay of Fundy. Marine Geology 124, 71-85.

Gehrels W.R., Belknap D.F., Kelley J.T. (1996) - Integrated high-precision analyses of Holocene relative sea-level changes: Lessons from the coast of Maine. Geological Society of America Bulletin 108, 9, 1073-1088.

Hallégouët B., Van Vliet- Lanoë B. (1986) - Les oscillations climatiques entre 125000 ans et le maximum glaciaire, d'après l'étude des formations marines, dunaires et périglaciaires de la côte des Abers (Finistère). Bulletin de l'Association française pour l'étude du Quaternaire, 23, 1-2, 127-138.

Heyworth A. and Kidson C. (1982) - Sea-level change in southwest England and Wales. Proceedings of the Geological Association 93-1, 91-111.

Horton B., Shennan I. (2009) - Compaction of Holocene strata and the implications for relative sea level change on the east coast of England. Geology 37, 12, 1083-1086.
Jelgersma S. (1961) - Holocene sea-level changes in The Netherlands. Mededelingen van de Geologische Stichting, serie C VI 7 , $1-100$.

Kemp A.C., Vane C.H., Horton B.P., Culver S.J. (2010) - Stable carbon isotopes as potential sea-level indicators in salt marshes, North Carolina, USA. The Holocene 20, 623-636.

Lamb H.H. (1977) - Climate: Present, Past and Future. Vol. 2, Climatic History and the Future. Methuen, London, 835 p.

Lamb A.L., Wilson G.P., Leng M.J. (2006) - A review of coastal palaeoclimate and relative sea-level reconstructions using $\mathrm{d} 13 \mathrm{C}$ and C/N ratios in organic material. Earth-Science Reviews 75, 29-57.

Lamb A.L., Vane C.H., Wilson G.P, Rees J.G., Moss-Hayes V.L. (2007) - Assessing $\delta^{13} \mathrm{C}$ and $\mathrm{C} / \mathrm{N}$ ratios from organic material in archived cores as Holocene sea level and palaeoenvironmental indicators in the Humber Estuary, UK. Marine Geology 244, 109-128.

Lambeck K. (1997) - Sea-level change along the French Atlantic and Channel coasts since the time of the Last Glacial Maximum. Palaeogeography, Palaeoclimatology, Palaeoecolecology 129, 1-2, 1-22.

Leorri E., Cearreta A., Milne G. (2012) - Field observations and modeling of Holocene sea-level changes in the southern Bay of Biscay: implications for understanding current rates of relative sea-level change and vertical land motion along the Atlantic coast of SW Europe. Quaternary Science Reviews 42, 59-73.

Long A.J., Hughes P.D.M. (1995) - Mid- and late-Holocene evolution of the Dungeness foreland, UK. Marine Geology 124, 253-271.

Long A.J., Plater A.J., Waller M.P., Innes J.B. (1996) Holocene coastal sedimentation in the Eastern English Channel. New data from the Romney Marsh region, United Kingdom. Marine Geology 136, 97-120.

Long A.J., Shennan I. (1998) - Models of rapid relative sea-level change in Washington and Oregon, USA. The Holocene 8, 129142 .

Long A.J., Waller M.P., Stupples P. (2006) - Driving mechanisms of coastal change: Peat compaction and the destruction of late Holocene coastal wetlands. Marine Geology 225, 63-84.

Makaske B., Van Smeerdijk D.G., Peeters H., Mulder J.R., Spek T. (2003) - Relative water-level rise in the Flevo lagoon (The Netherlands), 5300-2000 cal. yr BC: an evaluation of new and existing basal peat time-depth data. Netherlands Journal of Geoscience 82, 2, 115-131.

Massey A.C., Gehrels W.R., Charman D.J., White S.V. (2006a) - An intertidal foraminifera-based transfer function for reconstructing Holocene sea-level change in southwest England. Journal of Foraminiferal Research 36, 3, 215-232.

Massey A.C., Paul M.A., Gehrels W.R., Charman DJ. (2006b) - Autocompaction in Holocene coastal back-barrier sediments from south Devon, southwest England, UK. Marine Geology 226, 3-4, 225-241.

Massey A.C., Gehrels W.R., Charman D.J., Milne G.A., Peltier W.R., Lambeck K., Selby K.A. (2008) - Relative sea-level change and postglacial adjustment along the coast of south Devon, UK. Journal of Quaternary Science 23, 5, 415-433.

Monnier J.-L. (1973) - Contribution à l'étude des dépôts quaternaires de la région de Saint-Brieuc.Stratigraphie et sédimentolo- 
gie des limons, des plages et des sols anciens. Thèse de troisième cycle, Travaux du Laboratoire d'Anthropologie de Rennes, $260 \mathrm{p}$.

Morhange C., Marriner N., Laborel J., Todesco M., Oberlin C. (2006) - Rapid sea-level movements and non-eruptive crustal deformations in the Phlegrean Fields caldera, Italy. Geology 43, 2, 93-6.

Morzadec-Kerfourn M.-T. (1974) - Variation de la ligne de rivage armoricaine au Quaternaire. Analyses polliniques de dépôts organiques littoraux. Ph.D thesis, University of Rennes 1, 208 p.

Morzadec-Kerfourn M.-T. (1995) - Coastline changes in the Armorican Massif (France) during the Holocene. Journal of Coastal Research, Special Issue 17, 197-203.

Moura D., Veiga-Pires L., Albardeiro T., Boski T., Rodrigues A.L., Tareco H. (2007) - Holocene sea level fluctuations and coastal evolution in the central Algarve (southern Portugal). $M a$ rine Geology, 237, 127-142.

Pailler Y., Gandois H., Tresset A. (2011) - Beg ar Loued : un habitat en pierres sèches campaniforme/âge du Bronze ancient. Programme Archéologique Molénais, rapport n 15, 91 p.

Pirazzoli P.A., Pluet J. (1991) - World atlas of Holocene sea-level changes. Elsevier, Oceanography series 58, Amsterdam, 300 p.

Redfield A.C., Rubin M. (1962) - The age of salt marsh peat and its relation to recent change in sea level at Barnstable Massachusetts. Proceedings of the National Academy of Sciences of the U.S.A 48, 1728-1735.

Reimer P. J., Baillie M. G. L., Bard E., Bayliss A., Beck J. W., Blackwell P. G., Bronk Ramsey C., Buck C. E., Burr G. S., Edwards R. L., Friedrich M., Grootes P. M., Guilderson T. P., Hajdas I., Heaton T. J., Hogg A. G., Hughen K. A., Kaiser K. F., Kromer B., McCormac F. G., Manning S. W.,Reimer R. W.,Richards D. A.,Southon J. R.,Talamo S., Turney C. S. M.,Van der Plicht J.,Weyhenmeyer C. E.(2009) - Intcal09 and marine09 radiocarbon age calibration curves, $0-50,000$ years cal bp.. Radiocarbon 51, 1111-1150.

Scourse J.D. (1991) - Late Pleistocene stratigraphy and palaeobotany of the Isles of Scilly. Philosophical Transactions: Biological Sciences 334, 1271, 405-448.

Scourse J.D., Austin W.E.N., Bateman R.M., Catt J.A., Evans C.D.R., Robinson J.E., Young J.R. (1990) - Sedimentology and micropalaeontology of glacimarine sediments from the Central and South western Celtic Sea. In Dowdeswell J.A., Scourse J.D. (Eds.), Glaciomarine Environments: Processes and Sediments. Geological Society Special Publication 53, 329-347.

Shennan I. (1982) - Interpretation of the Flandrian sea-level data from the Fenland, England. Proceeding of the Geologists' Association 93, 53-63.

Shennan I. (1986) - Flandrian sea-level changes in the Fenland, II: tendencies of sea-level movement, altitudinal changes, and local and regional factors. Journal of Quaternary Science 1-2, 155-179.

Shennan I. (2007) - Overview - Sea-level studies. In Scott A.E. (Ed.): Encyclopedia of Quaternary Science. Elsevier, Amsterdam, 2967-2974.

Shennan I., Horton B. (2002) - Holocene land- and sea-level changes in Great Britain. Journal of Quaternary Science 17, 5$6,511-526$
Shennan I., Milne G., Bradley S. (2012) - Late Holocene vertical land motion and relative sea-level changes: lessons from the British Isles. Journal of Quaternary Science 27, 1, 64-70.

Stephan P. (2011) - Colmatage sédimentaire des marais maritimes et variations relatives du niveau marin au cours des 6000 dernières années en rade de Brest (Finistère). Norois 220, 3, 9-37.

Suanez S., Dehouck A., Stephan P. (2008) - Incertitude de la mesure de terrain en géomorphologie littorale. Approche statistique et quantification des marges d'erreur. Société d'Écologie Humaine, 127-139.

Ters M. (1973) - Les variations du niveau marin depuis 10000 ans le long du littoral atlantique français. In Le Quaternaire, géodynamique, stratigraphie et environnement. CNRS, Paris, 114-135.

Ters M. (1986) - Variations in Holocene sea level on the French Atlantic coast and their climatic significance. In Rampino M.R., Sanders J.E, Newman W.S, Königsson L.K. (Eds.), Climate: History, Periodicity and Predictability. Van Nostrand Reinhold, New York, 204-237.

Törnqvist T.E. (1993) - Fluvial sedimentary geology and chronology of the Holocene Rhine-Meuse delta, the Netherlands. Ph.D thesis, Utrecht University, $169 \mathrm{p}$.

Törnqvist T.E., Van Ree M.H.M., Van't Veer R., VanGeel B. (1998) - Improving methodology for high-resolution reconstruction of sea-level rise and neotectonics by paleoecological analysis and AMS ${ }^{14} \mathrm{C}$ dating of basal peats. Quaternary Research 4, Marine Geolology 9, 72-85.

Törnqvist T.E., Gonzales J.L., Newsom L.A., Van der Borg K., De Jong A.F.M., Kurnik C.W. (2004) - Deciphering Holocene sea-level history on the U.S. Gulf Coast: A high-resolution record from the Mississippi Delta. Geological Society of America Bulletin 116, 7-8, 1026-1039.

Törnqvist T.E., Bick S.J., Van der Borg K., De Jong A.F.M. (2006) - How stable is the Mississippi Delta? Geology 34, 697-700.

Uheara K., Scourse J.D., Horsburgh K.J., Lambeck K., Purcell A.P. (2006) - Tidal evolution of the northwest European shelf seas from the Last Glacial Maximum to the present. Journal of Geophysical Research 11, Issue C9.

Van de Plassche O. (1982) - Significance of a new basal peat date for the trend of Holocene mean sea level rise in The Netherlands. Geologie en Mijnbouw 61, 397-399.

Van de Plassche O. (1986) - Sea-level research: a manual for the collection and evaluation of data. Geobooks, Norwich, $617 \mathrm{p}$.

Van de Plassche O. (1991) - Coastal submergence of the Netherlands, NW Brittany (France), Delmarva Peninsula (VA, USA) and Connecticut (USA) during the last 5500 to 7500 sidereal years. In Sabadini R. (Ed.): Glacial Isostasy, Sea Level and Mantle Rheology. Kluwer, Dordrecht, 285-300.

Van de Plassche O. (1995) - Evolution of the intra-coastal tidal range in the Rhine - Meuse delta and Flevo Lagoon, 5700 3000 yrs cal B.C. Marine Geology 124, 113-128.

Van Geel B., Buurman J., Waterbolk H.T. (1996) - Archeological and paleoecological indications for an abrupt climate change in The Netherlands and evidence for climatological teleconnections around 2650 BP. Journal of Quaternary Science 11, 451-460. 
Vink A., Steffen H., Reinhardt L., Kaufmann G. (2007) Holocene relative sea-level change, isostatic subsidence and the radial viscosity structure of the mantle of northwest Europe (Belgium, theNetherlands, Germany, southern North Sea). Quaternary Science Reviews 26, 3249-3275.

Wilson G.P., Lamb A.L., Leng M.J., Gonzales S., Huddart D. (2005) - Variability of organic $d 13 \mathrm{C}$ and $\mathrm{C} / \mathrm{N}$ in the
Mersey Estuary, U.K. and its implications for sea-level reconstruction studies. Estuarine Coastal Shelf Science 64, 685-698.

Wintle A.G. (1981) - Thermoluminescence dating of Devensian loesses in Southern England. Nature 289, 479-480.

Article soumis le 29 juin 2012, accepté le 24 septembre 2013. 